Portland State University

PDXScholar

8-1-1975

\title{
Course Demands of Students in Teacher Education at Portland State University as Demonstrated by an Induced Course Load Matrix
}

Elinore Janet Rogers

Portland State University

Follow this and additional works at: https://pdxscholar.library.pdx.edu/open_access_etds

Part of the Curriculum and Instruction Commons

Let us know how access to this document benefits you.

\section{Recommended Citation}

Rogers, Elinore Janet, "Course Demands of Students in Teacher Education at Portland State University as Demonstrated by an Induced Course Load Matrix" (1975). Dissertations and Theses. Paper 2353.

https://doi.org/10.15760/etd.2350

This Thesis is brought to you for free and open access. It has been accepted for inclusion in Dissertations and Theses by an authorized administrator of PDXScholar. Please contact us if we can make this document more accessible: pdxscholar@pdx.edu. 
AN ABSTRACT OF THE THESIS OF Elinore Janet Rogers for the Master of Science in Education presented August 1, 1975.

Title: Course Demands of Students in Teacher Education at Portland State University as Demonstrated by an Induced Course Load Matrix.

APPROVED BY MEMBERS OF THE THESIS COMMITTEE:
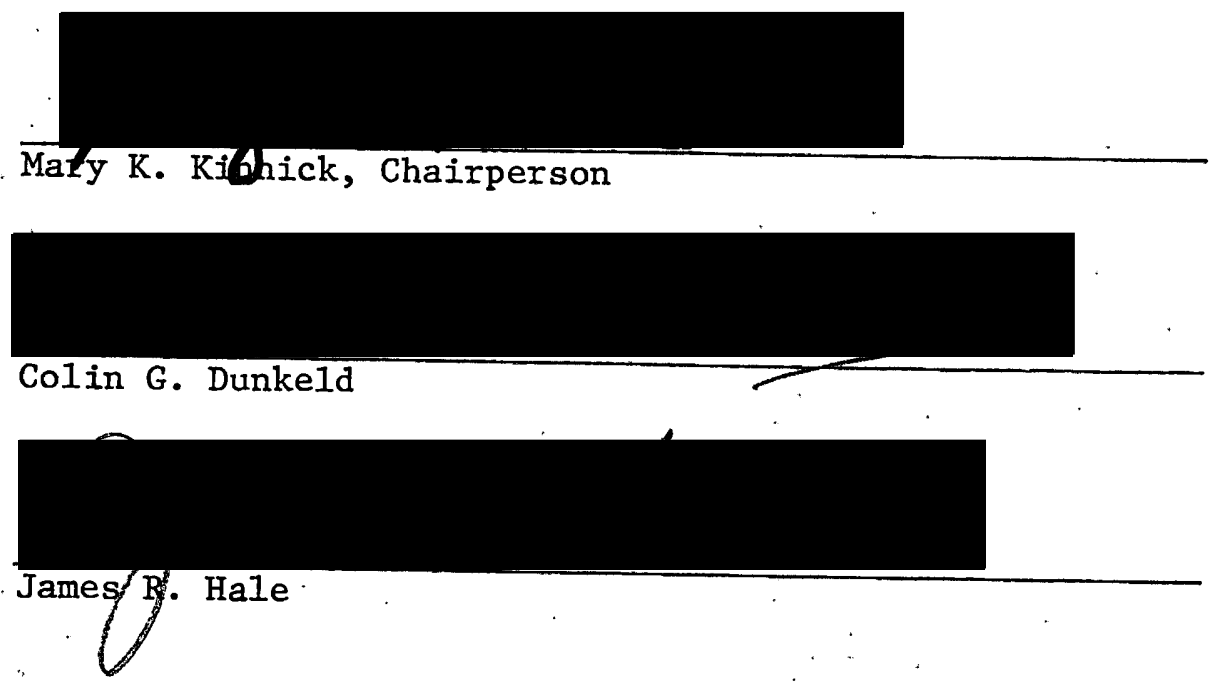

The purpose of this study was to examine the interrelationships between the School of Education and the rest of the university by means of the course demands placed by elementary education majors and graduate education students on other academic departments during the fall terms of 1972 and 1973. It also examined the course demands placed on the School of Education by other major groups for this period. The Induced Course Load Matrix (ICLM) was the vehicle used in this examination. The hypotheses tested were 1). that elementary 
education majors and graduate education students placed equal course demands on the other academic departments, 2) that other major groups place equal course demands on the School of Education, and 3), that course demands by these three groups were consistent over time.

Results indicated that elementary education majors and graduate education students did not place equal demands on other academic departments. Elementary education majors placed the greatest course demands, as might be expected, on departments where there are course requirements such as Psychology, English, General Science, Mathematics and Speech.. However, this group also placed heavy course demands on the History Department even though there are no required courses. Graduate education students placed course demands on other academic departments similar to elementary education majors, especially in the Departments of Psychology, English and History.

Other major groups did not place equal demands on the School of Education. Major groups for which there are direct secondary teacher education programs placed the greatest course demands. These included majors in Business Education, Health and Physical Education, Speech and Hearing, General Social Science and the foreign languages of Spanish, French and German. Major groups for which there is no direct teacher education placed few course demands on the School of Education.

These course demands have been consistent over time with one exception. The exception was for graduate education students who placed greater course demands on the Politfcal Science Department during fall term, 1972 than during fall term, 1973. 
The implications are that if there is an increase in the enrollment of elementary education majors or graduate education students, it can be predicted that there will be an increase of course demands placed on other academic departments, such as Psychology, English and History. Also, if there is an increase in the enrollment of other major groups for which there are secondary teacher education programs, there will be an increase of course demands placed on the School of Education. 
COURSE DEMANDS OF STUDENTS IN TEACHER EDUCATION AT PORTLAND STATE UNIVERSITY AS DEMONSTRATED BY AN INDUCED COURSE LOAD MATRIX

by

Elinore Janet Rogers

A thesis submitted in partial fulfillment of the requirements for the degree of

\author{
MASTER OF SCIENCE \\ in \\ EDUCATION
}

Portland State University

1975 
TO THE OFFICE OF GRADUATE STUDIES AND RESEARCH:

The members of the Committee approve the thesis of Elinore Janet Rogers presented August 1, 1975.

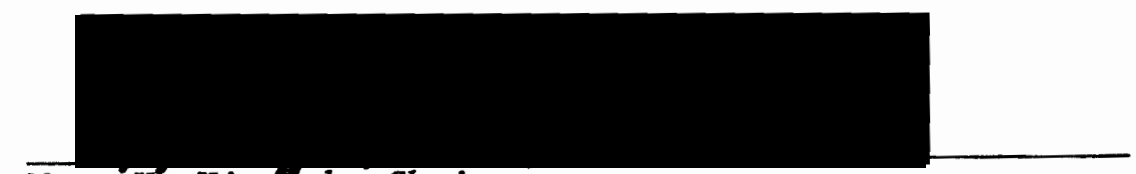
Mary K. Kinrack, Chairperson
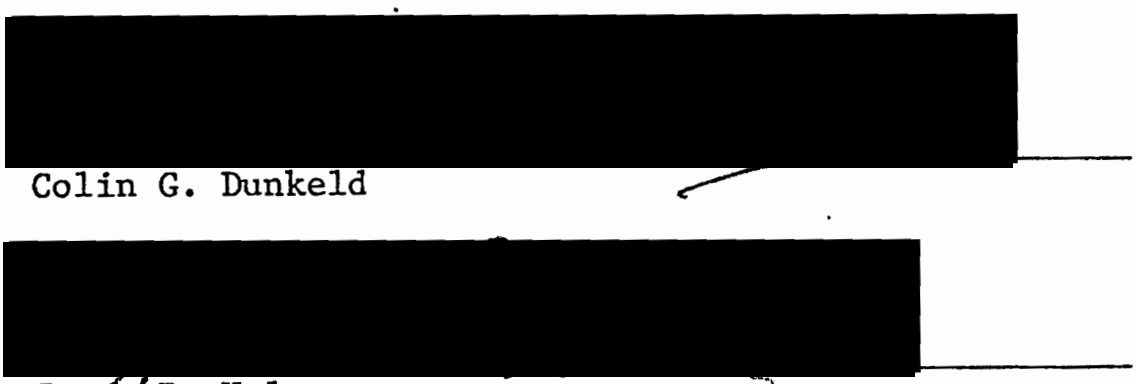

Jamég $\mathrm{R}$. Hale

APPROVED :

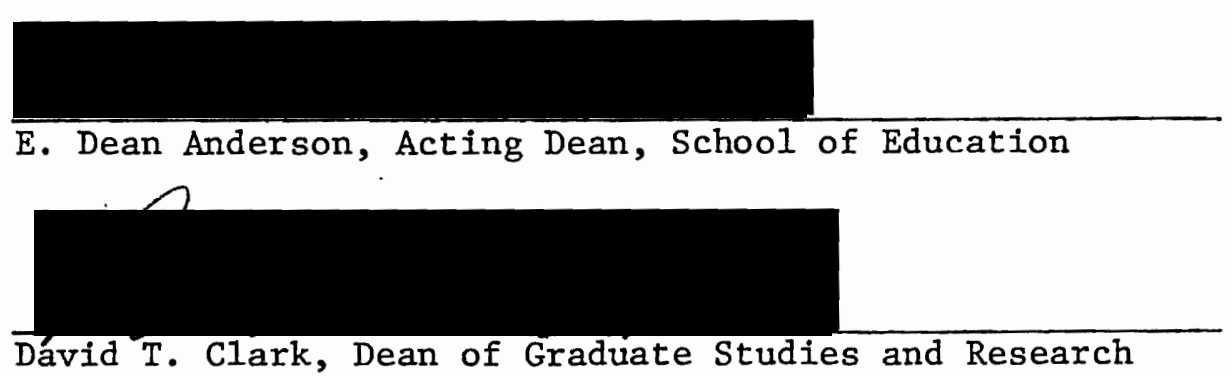


TABLE OF CONTENTS

PAGE

LIST OF TABLES. . . . . . . . . . . . . . . . . .

CHAPTER

I STATEMENT OF THE PROBLEM. . . . . . . . . . . 1

Background ................. . . 1

Statement of the Problem . . . . . . . . 4

II REVIEW OF RELATED LITERATURE. . . . . . . . . 8

Induced Course Load Matrix (ICLM). . . . . 8

Cost Simulation Models ......... . 11

III PROCEDURES AND RESULTS. . . . . . . . . . 16

Procedures ............. . . 16

Results . . . . . . . . . . . . 40

IV ANALYSIS AND DISCUSSION. . . . . . . . . . . 46

Elementary Education Majors . . . . . . 46

Graduate Education Students . . . . . . 50

Course Demands of Other Major Groups

on Education.......... 53

$\mathrm{V}$ SUMMARY AND IMPLICATIONS. . . . . . . . . 57

BIBLIOGRAPHY. . . . . . . . . . . . . . . . . 62

APPENDIX. . . . . . . . . . . . . . . . . . 65 


\section{LIST OF TABLES}

PAGE

TABLE

I Average Hours Taken by an FTE Education Major by

Student Level by Class Level in Each.

Department . . . . . . . . . . . .

II Average Hours Taken in Education by Major Groups

by Student Level and Course Level . . . . .

III Major Groups Not Included in Study With Total FTE

Enrollment for Fall 1972 and Fall 1973 ....

IV Analysis of Variance . . . . . . . . . . .

$\mathrm{V}$ Calculations of $\underline{t}$-Tests for Elementary Education

Majors and Graduate Education Students ....

VI Calculations of $t$-Tests for Other Major Groups on

Education . . . . . . . . . . . . 
CHAPTER I

STATEMENT OF THE PROBLEM

\section{Background.}

Teacher education programs for which Portland State University is approved reflect the certification requirements of the Oregon Teacher Standards and Practices Commission as well as university degree requirements.

The School of Education offers basic certification programs at the undergraduate level in elementary education and in secondary education in the following fields: art, English, music, foreign language (Spanish, French, and German); speech, theater arts, mathematics, biology; chemistry, general science, physics, earth science, social science, health, physical education, and business education. There are also equivalency programs in all of the above areas for students who already have a baccalaureate degree and want to meet teacher education requirements for basic certification. At the graduate level, the School of Education in conjunction with the university offers Masters of Arts and Masters of Sclence in Education as we11 as Masters of Arts in Teaching and Masters of Science in Teaching degrees. The MA and MS degree require that a majority of coursework be taken in education courses, while the MAT and MST degree require a majority of coursework to be taken in subject areas. Elementary education students will usually pursue an MA or MS degree 
combined with a standard elementary certificate. Secondary education students will generally pursue a MAT or MST degree in their teaching field combined with a standard secondary certificate. Those who wish to concentrate in a specialist program also pursue the MA or MS degree. Specialist programs include basic and standard certification in educational media, special education, counseling, administration and supervision.

At Portland State University, teacher education is a university wide function: The School of Education functions within and throughout the university. It functions within the university as an agency for students intending to become elementary or secondary teachers by offering approved teacher preparation programs. It also offers teachers in elementary or secondary education the opportunity to gain additional certification or preparation in one of the specialist programs.

The School of Education functions throughout the university by requiring that students take specific courses. For example, all basic teacher education programs require that students have a general psychology course as well as Human Development, Psychology 311. In this instance, an increase or decrease in the number of teacher education students would have an immediate Impact on the Psychology. Department: A speech course is also a general education requirement, so that the same impact would hold true for the Speech Department. In the elementary education program, courses in art, music, mathematics, biological and physical science are also required. This indicates that the resource requirements of these departments are also affected by the 
teacher education program. Therefore, the course demands of students in teacher education programs play an important part in the course demands and in the resource requirements of the university as a whole. The School of Education additionally functions within the university in that teacher education students place course demands directly on the School of Education. At the undergraduate level, a student who is an education major and is therefore, preparing to be an elementary teacher will take a minimum of 42 credits in education courses. The remainder of the course demands are made on the various other departments of the university. Other majors in the university who are planning to teach at the secondary level take the majority of their courses in their major department or college, but place course demands on the School of Education. These students must take a minimum of 27 to 30 credits in education courses. At the graduate level, the masters and certificate program require courses in education and in the other academic departments. While the MA/MS in Education has required a minimum of 24 credits in education courses and a minimum of 9 credits in other academic courses, the MAT/MST program has required the reverse or a minimum of 30 credits in other academic courses and a minimum of 9 credits in education courses. There is, therefore, an interdependency between the School of Education and the university as a whole. The School of Education depends on the rest of the university to provide elementary education majors academic preparation in subject matter. While the school of Education provides preparation in educational theories, strategies and the experiences needed for teaching at the elementary level, other 
academic departments depend on the School of Education to provide their majors with the expertise in the art of teaching at the secondary level.

\section{Statement of the Problem}

Long range planning and cost analysis have become increasingly important for higher education during the last ten years. At one time, enrollment was evergrowing and social and economic factors were favorable for continued growth. Then, however; enrollment began to decline. The public began to demand that colleges and universities make more effective use of their resources, both fiscal and human, as the competition among many other governmental agencies and organizations for public dollars became more intense. As a consequence, higher education has had to scrutinize more carefully how effectively it is using current resources to carry out programs. The teacher education program at Portland State University with its interrelationships within and throughout the university, is one program engaging in a review of its utilization of resources.

The purpose of this study is to examine the interrelationship between the School of Education and the university more closely. This examination can be made by seeking answers to some basic questions. 1) On which departments throughout the university do elementary education majors place course demands and what is the extent of those demands? 2) Which departments throughout the university place course demands on the School of Education and what is the extent of these demands? 3) On which departments do graduate students in education place course demands and what is the extent of those demands? 4) Are the course 
demands of elementary education majors and graduate students in eduction on other departments stable over time? 5) Are the course demands of other student major groups on the Schooil of Education stable over time?

The implications of this examination are multi-faceted. First, by examining the course demands of education students, better communication with departments where education students are placing course demands can be established. Also, the converse is applicable. By examining the education course demands of other student major groups, better communication with advisers in departments for those groups who are placing the greatest demands can also be established. Second, by knowing the course demands, their extent and stability, future planning can take into consideration an increase or decrease in the number of students planning to teach at the elementary. or secondary level. Also, if there are changes in the number of graduate students, changes can also be predicted. For instance, if it can be determined that an elementary education student takes an average of .50 credit hours in history and the number of elementary education students increase by 50 , it could be expected that the history department would have to anticipate an additional demand of 25 credit hours on their department for these students. A further implication in terms of planning has to do with the course taking behavior of elementary education students. It is desirable that these students have a broad background in the areas of art, social science and science. If it is found that elementary education students are limiting their course demands to certain departments, advisers could, 
therefore, begin placing emphasis on those areas of need that are not being incorporated into student programs.

Third, this study seeks to give the university as a whole an awareness of the contribution the School of Education makes to the enrollment of the university in that many students come to Portland State University because they want to become teachers or receive additional teacher training.

Fourth, it is hoped that this study will serve as a model for other departments throughout the university who wish to investigate the course demands of their own majors as well as determining which other student major groups they are serving and to what extent.

Research Questions: Does the average elementary education major take as many credit hours in history as he does in art, English, music, biology and other academic departments? Does this demand change over time?

Hypotheses: Elementary education majors place equal demands on each of the academic departments outside education for coursework. These demands have remained consistent over time.

Research Questions: Do other departments each make equal demands on the School of Education. For instance, does the average history major take as many credit hours in education courses as the average art, English, music or biology major? Does this demand change over time? 
Hypotheses:

Research Questions:

Hypotheses:
Other major groups place equal demands on the School of Education for coursework. These demands have remained consistent over time.

Does the average graduate student in education take as many credit hours in history as he does in art, English, music, biology and the other academic departments? Does this demand change over time?

Graduate students in education place equal demands on academic departments outside education for coursework. These demands have remained consistent over time.

The vehicle that will be used to measure these course demands is the Induced Course Load Matrix (ICLM). The ICLM is a foundation of the Resource Requirements Prediction Model (RRPM), a cost simulation model used in higher education. Basically, the ICLM computes the average number of credits the average full time equivalent (FTE) major takes in each department across the university. Knowledge of the course demand patterns of a particular major group would allow for the prediction of the level of future course demand, given an increase or decrease in the number of students enrolled in that major. 
A search of the 1iterature reveals that there has been little research published on the Induced Course Load Matrix (ICLM). A brief explanation of the ICLM is in order as well as some discussion about the larger concept of cost simulation models and in particular, those used in higher education.

\section{Induced Course Load Matrix (ICLM)}

An ICLM has both an historical and predictive aspect. Historically, it describes the relationship between student major groups and departments by calculating the average number of hours the average major takes in each department. The ICLM is derived by dividing the number of full time equivalent (FTE) students in a particular major into the total credit hours taken in each academic department. This can be expanded to show the ICLM by student level (1.e., freshman, sophomore, junior, senior, graduate) within the major and/or course leve1 within each department (i.e., lower division, upper division, upper division-graduate, graduate). The total credit hours taken is referred to as the Induced Work Load Matrix (IWLM). The diagram below displays the IWLM by student level for undergraduate elementary education students in three academic departments for fall term, 1973 and the calculations of the ICLM. 
Freshmen Sophomore Junior Seniors

\begin{tabular}{lccccc} 
English & 125 & 152 & 162 & 112 & \\
Mathematics & 105 & 34 & 103 & 35 & IWLM \\
Psychology & 66 & 127 & 231 & 69 & $\div$ \\
\hline & 63 & 72 & 142 & 157 & FTE \\
\hline English & 1.98 & 2.11 & 1.14 & .71 & \\
Mathematics & 1.66 & .47 & .72 & .22 & \\
Psychology & 1.04 & 1.76 & 1.62 & .43 &
\end{tabular}

This IWLM shows that freshmen took 125 credit hours in English, 105 credit hours in mathematics and 66 credit hours in psychology. Total credit hours taken by sophomores, juniors and seniors in these three departments are also shown.

During this fall term, there were 63 FTE freshmen, 72 FTE sophomores, 142 FTE juntors and 157 FTE seniors in elementary education. Therefore, to calculate the ICLM for these three departments, the IWLM is divided by the FTE for each level.

The resulting ICLM indicates that the average FTE freshmen took 1.98 credit hours in English, 1.66 credit hours in mathematics, and 1.04 credit hours in psychology. The average sophomore took 2.11 credit hours in English, .47 credit hours in mathematics and 1.76 credit hours in psychology. The average junior took 1.14 credit hours In English, .72 credit hours in mathematics and 1.62 credit hours in psychology. The average senior took . 71 credit hours in English, 
.22 credit hours in mathematics and .43 credit hours in psychology for this fall term.

The ICLM becomes predictive by utilizing the historical data. For example, by knowing that the average freshman took 1.98 credit hours of English, it could be predicted that if there were 100 FTE elementary education freshman, they would take 198 credit hours of English and 166 credit hours in mathematics and 104 credit hours in psychology .

The predictive aspect of the ICLM, however, has some limitations. At Humboldt State College, Jewett, et al (1970) conducted a study on the question of the stability of the ICLM. Conclusions of this major study indicate that a prediction of course enrollment from one term to the following term is not meaningful. For example, a fall term ICLM cannot be accurately used to predict a winter or spring term enrollment. The predictive aspect is more correctly applied when an ICLM for one term is used to predict enrollment for the same term of the following year, i.e., using a fall term ICLM to predict a fall term enrollment (Jewett, et al 1970). An ICLM is also subject to Instability because of the changing enrollment behavior of student majors. While students may be taking credit hours in one department, the pattern may not continue to be consistent due to changes of student interests or changes of graduation or major requirements. Students may change majors from term to term, giving another element of instability to the ICLM. Furthermore, if the coding procedure used by the Admissions office or the Registrar for majors is not consistent, the ICLM loses some of its predictive quality. 


\section{Cost Simulation Models}

Some form of the ICLM is utilized in most cost simulation models In higher education for determining the resource requirements of the various programs. A cost simulation model mathematically describes the relationship between activities and the resources required to support these activities. These models also indicate the changes in resource requirements that would result from a change in the institutional activities. In these modes it is used for long range planning, programing and budgeting. Activities in higher education are usually defined in terms of courses, programs or student major groups. Resources are defined as personnel, facllities and equipment. Personnel resources include instructional staff, clerical staff, administrators and other supporting staff. Facility resources are defined as the space requirements needed for these activities, such as classrooms, gymnasiums, laboratories, and dormitories. Equipment resources include such items as media, laboratory supplies and stationery. Portions of these resources are then allocated to the activities as needs require. Therefore, given the cost per program, predictions can be made for long range planning given a change in the activities or programs.

Several cost simulation models have now been developed specifically for use in higher education. Some of these are SEARCH (System for Evaluating Alternative Resource Commitments in Higher. Education) developed by Peat, Marwick and Mitchell and Co., PLANTRAN developed by the Midwest Research Institute for the Kansas City 
Regional Council for Higher Education, CAMPUS (Comprehensive Analytical Methods of Planning a University System) developed by $R$. W. Judy and J. B. Levine in Toronto and RRPM (Resource Requirements Prediction Mode1) developed by the National Center for Higher Education Management Systems (NCHEMS) at the Western Interstate Commission for Higher Education (WICHE).

Eight small colleges made a collective effort to develop a model that would enable them to make realistic projections about enrollment and resources. This initial project was entitled, Computer Assisted Planning for Small Colleges (CAP:SC) which developed into SEARCH. However, Hopmann (1973) reports that there have been numerous problems involved with its utilization. Some of these problems include a lack of interest in the model on the part of the administrators, complexity of the model itself, and the inability of the model to perform as expected.

PLANTRAN is an outgrowth of HELP (Higher Education Long Range Planning). Adrian (1973) states that PLANTRAN is a completely different approach to the concept of planning, programming and budgeting and it is not really a model but merely a series of arithmetical calculations and projection techniques (Adrian, 1973, p. 46). It is extremely flextble in that it will accept data in any form, while other models will only accept data organized into a specific format. While this is an advantage as far as the speed in implementation, an institution is not likely to learn very much if there are inaccuracies and gaps in the data. The University of Denver has not felt that this system has been highly successful (Adrian; 1973). 
The CAMPUS model was adopted for implementation in 1972 by the University of Colorado. This model performs basicaliy the same function as the others in terms of planning, programming and budgeting, but it is very detailed and comprehensive. It focuses on activities and uses classes as the most disaggregated kind of basic activity. A class is defined in one of three ways: 1) lecture, 2) laboratory, or 3) consultation. Resources needed to support these activities are then related in terms of staff, space or equipment (Minter and Lawrence, 1969). This model is expensive to purchase and requires a sophisticated computer to run it (Hussain and Mason, 1973). However, Andrew (1973) feels that the experience of implementation at the University of Colorado has been worthwhile in the area of program planning.

In 1968, WICHE selected a cost simulation model developed by Dr. George Weathersby at the University of California at Berkeley after examination of several models. This model has been used successfully at the University of California at Berkeley and is conceptually simple in design so that administrators with little or no technical expertise will be able to make better use of it. It does. not need a highly'sophisticated computer to run it and therefore, is more adaptable to institutions with limited computer capabilities. Further development of the Weathersby model to reflect policies of WICHE resulted in Resource Requirement Prediction Model-1 (RRPM-1). This model was then pilot tested during 1970 to 1971 at eight institutions of which Portland State University was one. Types of institutions in the pilot study included a community college, state 
colleges, single campus, public and private universities, and colleges and universities which are part of a multi-campus system. Enrollment at the institutions ranged from under 2,000 to over 29,000. Much of the data needed for generation of the report was either not available in the form needed or had to be collected. While this data collection impeded efforts to get the model running, the importance of using accurate data for the purposes of accurate planning and programming was emphasized (Hussain and Martin, 1971). Refinements were made on RRPM-1 on recommendations from the pilot institutions, and in 1972, RRPM-1.6 was tested at the California State University at Fullerton. This Initial implementation provided Fullerton with insight into how resources had been used in the past and pointed the way for determining more efficient methods for future utilization. However, with all this information avallable, they stated that "the key to changing the planning and management cycle in an institution is people." (Implementation of NCHEMS Planning and Management Tools at California State University, Fullerton, 1972, p. 99). Administrators must learn how to use this new information in planning and analysis and to realize that sophisticated prediction models do not preclude the need to make subjective decisions. A cost simulation is only a tool to help make better decisions about questions of programming, planning, and budgeting. Evans (1972) concluded that among the institutions in which the administrators had greater knowledge about a particular model, there was a greater "tendency to accept and utilize information produced from the model. The ICLM is a basic element of the RRPM and all institutional costs are directly 
affected by it. Huff and Young state that "the ICLM provides useful ... management information even outside the context of RRPM." (Huff and Young, 1974, p. 9). Both the California and Oregon legislatures have adopted RRPM for use in their institutions of higher education. 
CHAPTER III

PROCEDURES AND RESULTS

\section{Procedures}

The course demands of elementary education majors and graduate education students on other academic departments and the course demands made on the School of Education by other major groups were used in order to examine the interrelationship between the School of Education and the university. Data were collected from IWLM-ICLM Reports issued by the Chancellor's office of the State System of Higher Education. These reports were compiled from data supplied by the offices of the Registrar and Administration and Management Information Systems at Portland State University. Table I and Table II display the ICLM data extracted from these reports that were used in the study; These figures include all students enrolled in the specified majors during the fall term for 1972 and fall term 1973. In the Tables, lower division (LD) refers to all courses numbered from 100 to 299. Upper division (UD) refers to courses numbered from 300 to 499 , excluding those courses with $400 \mathrm{G}$ numbers. Upper divisiongraduate (UD/G) refers to courses with $400 \mathrm{G}$ numbers which are offered for either graduate or undergraduate credit. Graduate (G) refers to a11 500 number courses.

Table I displays the average credit hours taken by the average FTE education major by student level, by department and leve1, for 
TABLE I

AVERAGE HOURS TAKEN BY AN FTE EDUCATION MAJOR BY STUDENT LEVEL BY CLASS LEVEL

IN EACH DEPARTMENT

\begin{tabular}{|c|c|c|c|c|c|c|c|c|c|c|c|c|c|}
\hline & Freshman & Soph & hore & Jun & ior & Sen & ior & Gra & ate & & & $\begin{array}{l}\text { Equiv } \\
\text { Pro }\end{array}$ & \\
\hline
\end{tabular}

\section{Department by Leve1} Art and Arch

$$
\text { LD } .27
$$

(.

$+\frac{10}{20}$

$181 \quad 142$

182.157

$\begin{array}{rrr}59 & 99 & 98\end{array}$

72

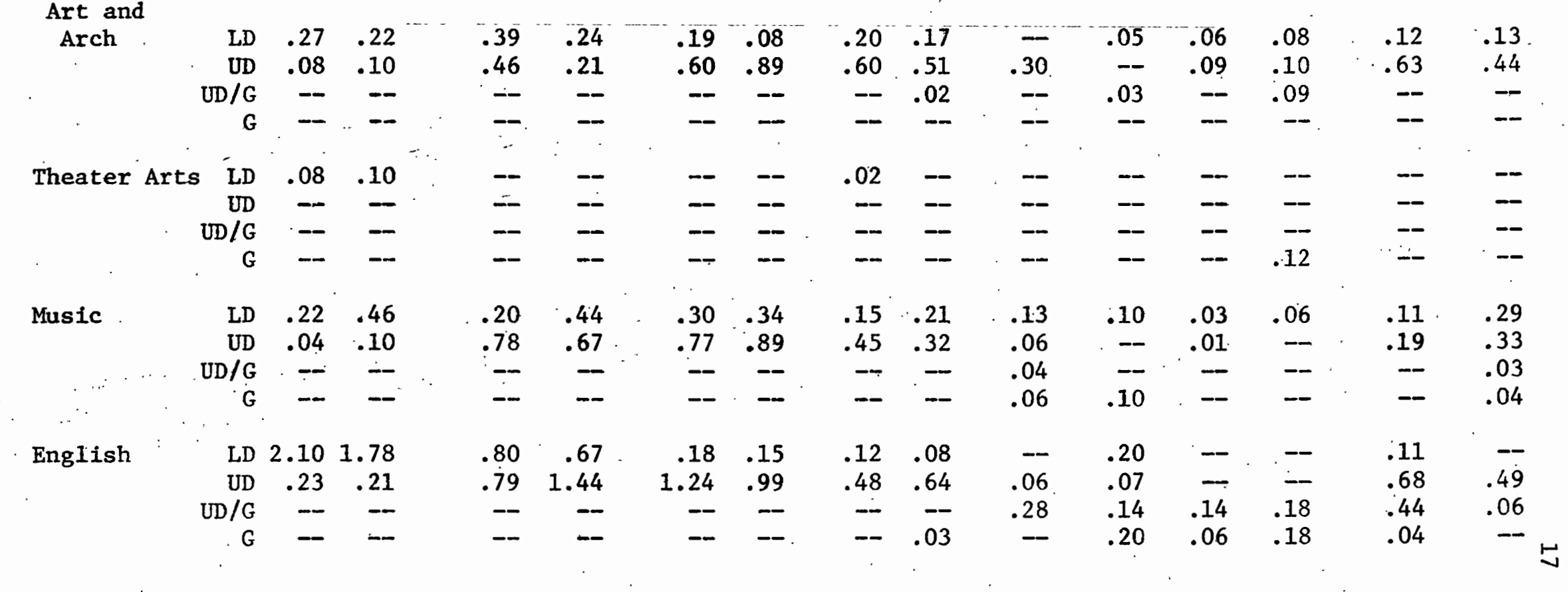


TABLE I (Continued)

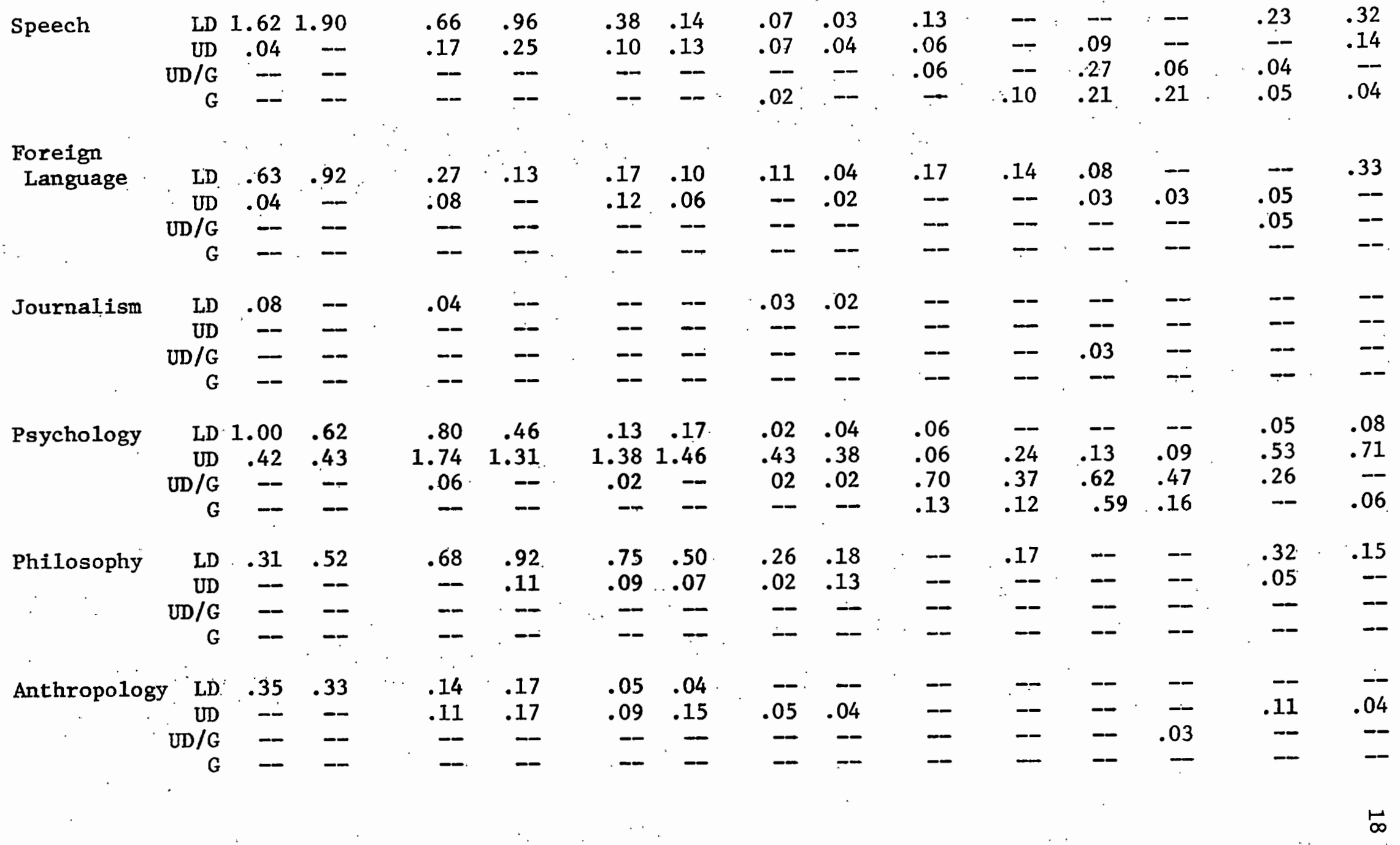


TABLE I (Continued)

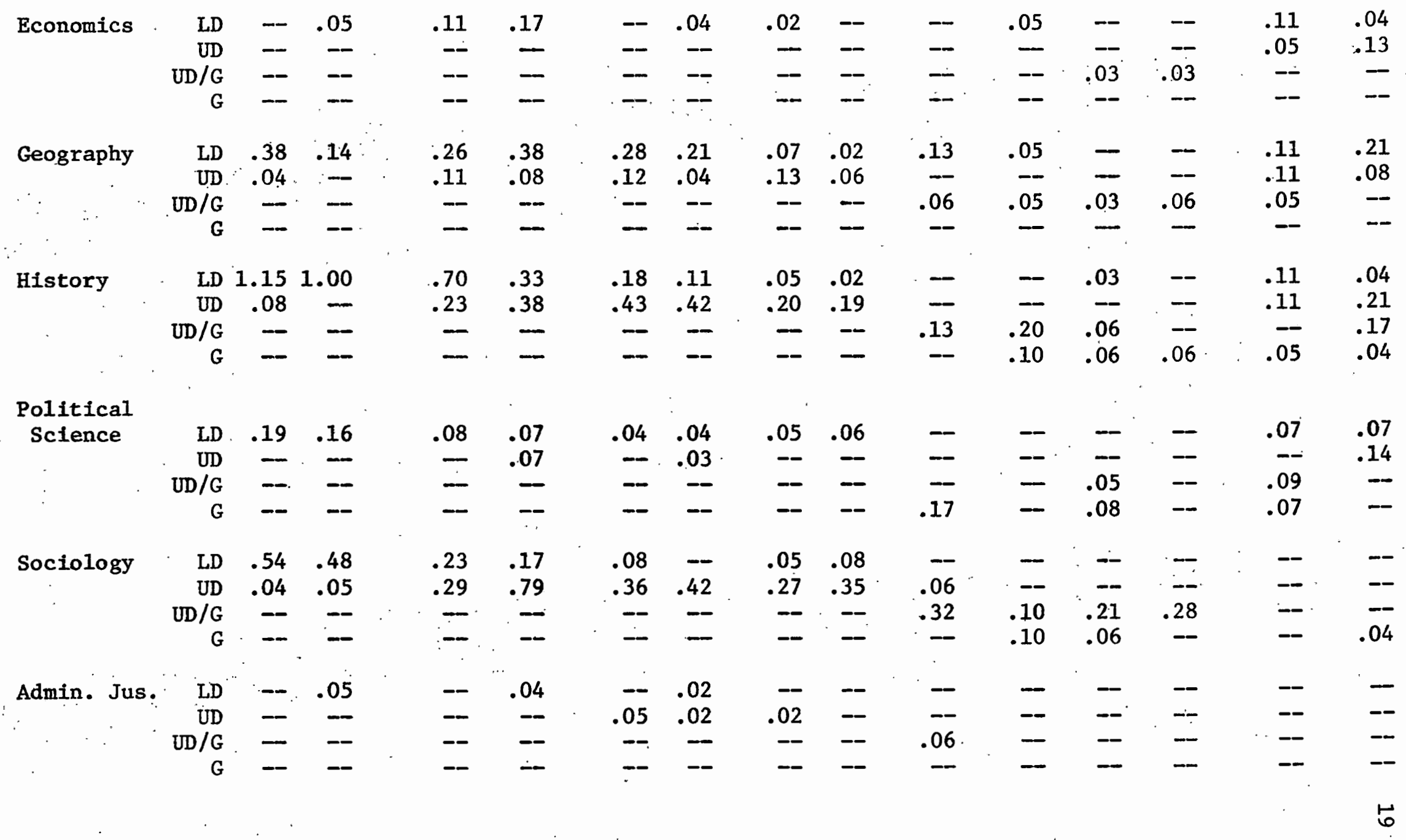


TABLE I (Continued)

\begin{tabular}{|c|c|c|c|c|c|c|c|c|c|c|c|c|c|c|c|}
\hline \multicolumn{16}{|l|}{ Applied } \\
\hline & UD & - & - & - & - & .02 & - & .02 & - & - & - & $-\dot{-}$ & - & .07 & - \\
\hline & UD/G & - & -- & - & -- & -- & - & - & -- & - & - & - & -- & -- & -- \\
\hline . & G & - & - & -- & $-\dot{-}$ & -- & -- & - & -- & - & -- & - & -- & - & $\rightarrow$ \\
\hline Biology & $L D$ & .32 & .56 & .19 & .11 & .15 & .08 & .03 & .04 & - & - & - & .03 & .05 & .04 \\
\hline & UD & - & - & .07 & .06 & .07 & .13 & .02 & .06 & -- & - & - & -- & - & .11 \\
\hline & $\mathrm{UD} / \mathrm{G}$ & - & -- & - & -- & - & -- & -- & -- & - & .05 & - & - & .05 & -- \\
\hline General & - & & & & & & & & & & & & & & \\
\hline Science & $L D$ & 1.35 & 1.24 & 1.54 & 1.08 & .91 & .76 & .35 & .19 & .13 & .05 & - & .03 & .26 & .29 \\
\hline & UD & - & - & .17 & .17 & .23 & .21 & .08 & .08 & - & - & - & .03 & .05 & .04 \\
\hline . & UD/G & - & - & - & -- & .03 & .02 & -- & -- & .06 & - & - & - & - & - \\
\hline & G & - & - & -- & - & - & -- & - & -- & - & - & - & - & - & - \\
\hline Mathematics & LD. & 1.76 & 1.57 & .51 & .39 & .60 & .58 & .14 & .15 & .15 & .10 & .06 & .03 & .19 & .43 \\
\hline Chemistry & LD & .27 & .10 & .04 & .10 & .09 & .08 & .03 & .02 & - & - & - & $\ldots$ & -- & .04 \\
\hline & UD & - & - & -- & - & - & - & - & - & -- & - & - & - & - & -- \\
\hline & $\mathrm{UD} / \mathrm{G}$ & - & -- & - & - & - & - & - & - & -- & - & - & -- & -- & -- \\
\hline & $G$ & $\because$ & - & -- & - & - & -- & -- & - & - & - & - & -- & - & - \\
\hline Physics & $L D$ & -- & - & -- & .04 & - & -- & $\therefore$ & -- & - & - & - & -- & - & - \\
\hline . & UD & - & -- & -- & -- & - & .02 & - & -- & .06 & - & -- & $\therefore$ & -- & $一$ \\
\hline & UD/G & - & - & -- & -- & - . & -- & - & $-\infty$ & - & - & -- & - & -- & $\because$ \\
\hline & G & -- & -- & -- & -- & - & -- & - & - & -- & - & - & -- & - & -- \\
\hline
\end{tabular}


TABLE I (Continued)

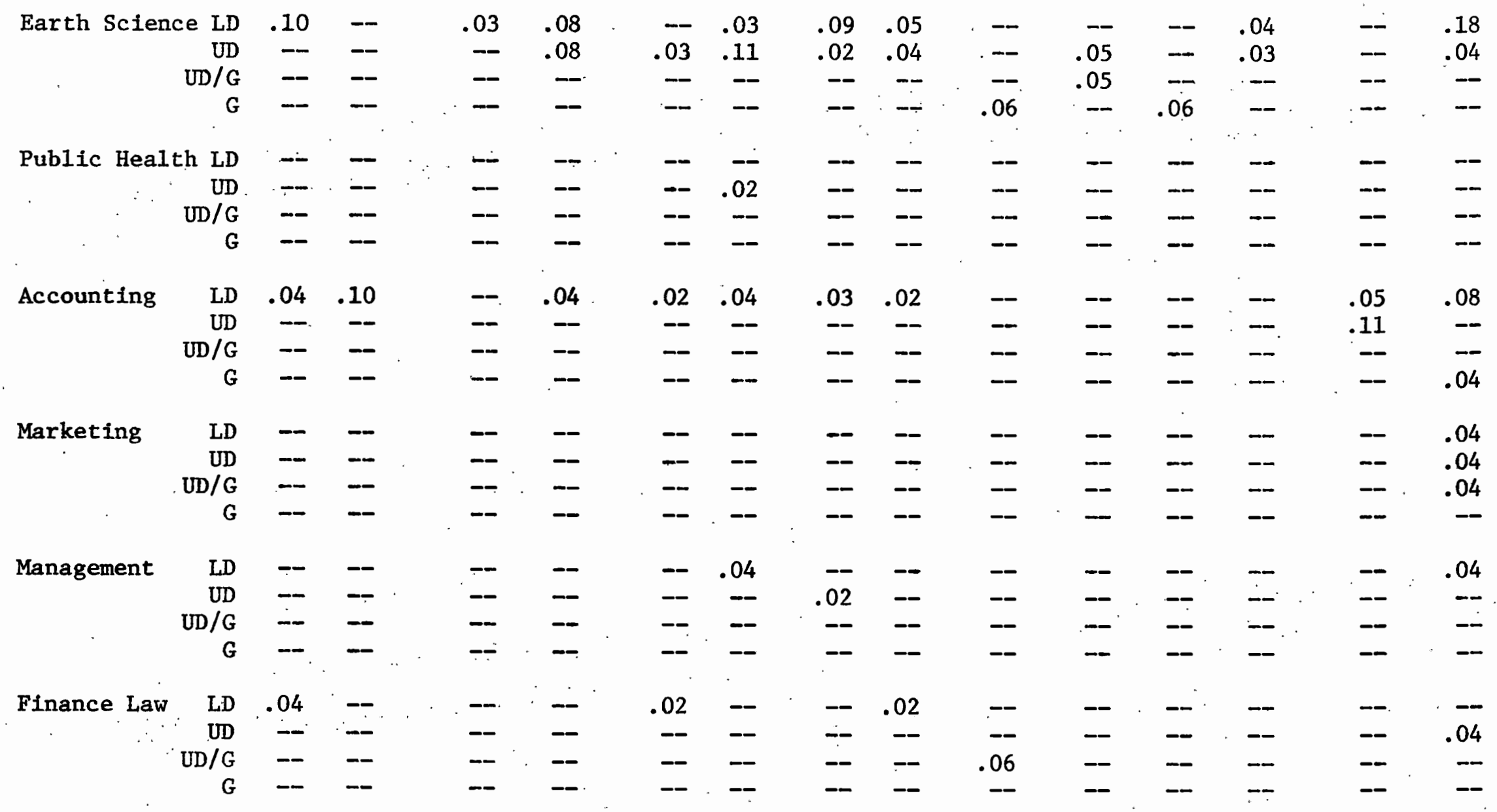


TABLE I (Continued)

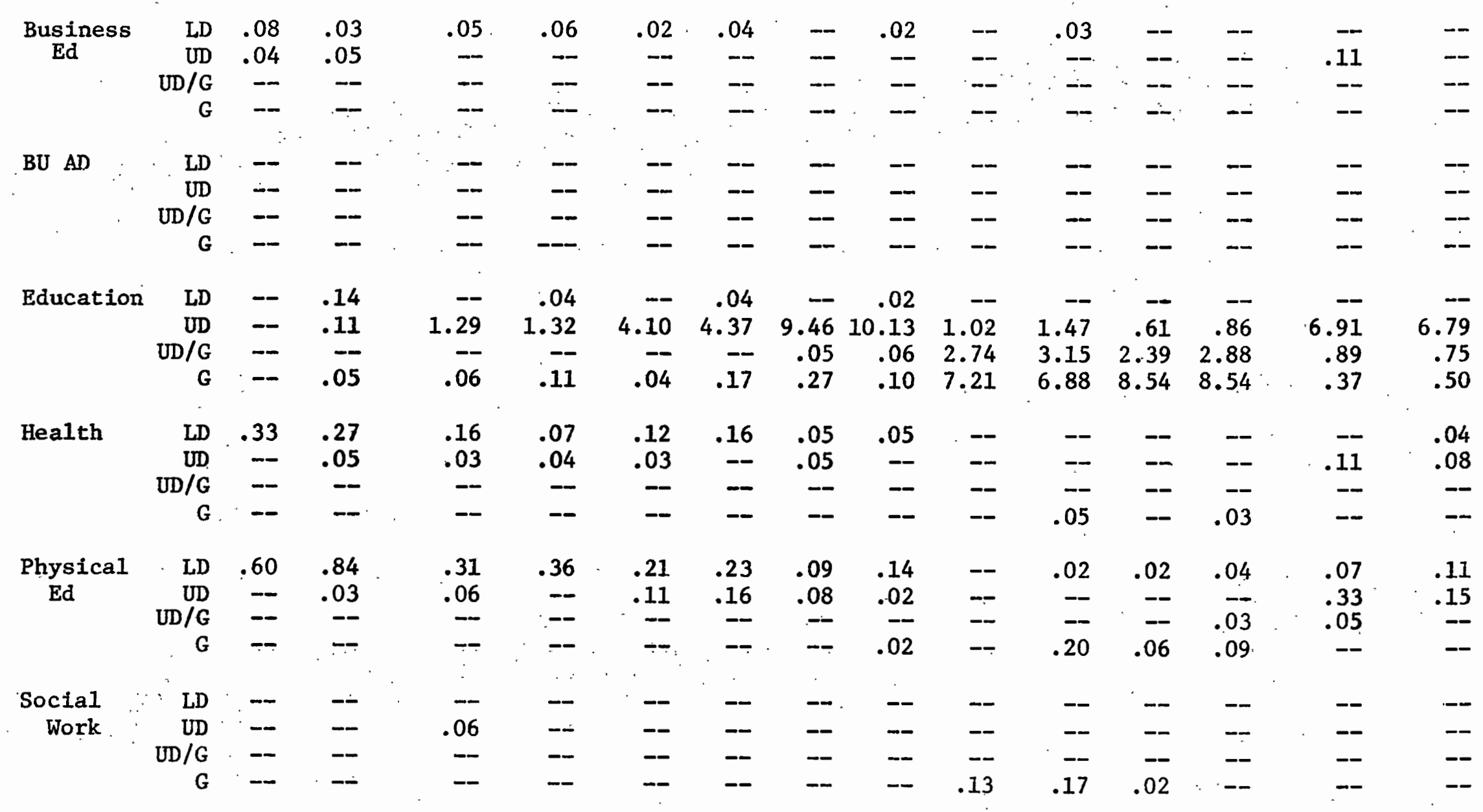


TABLE I (Continued)

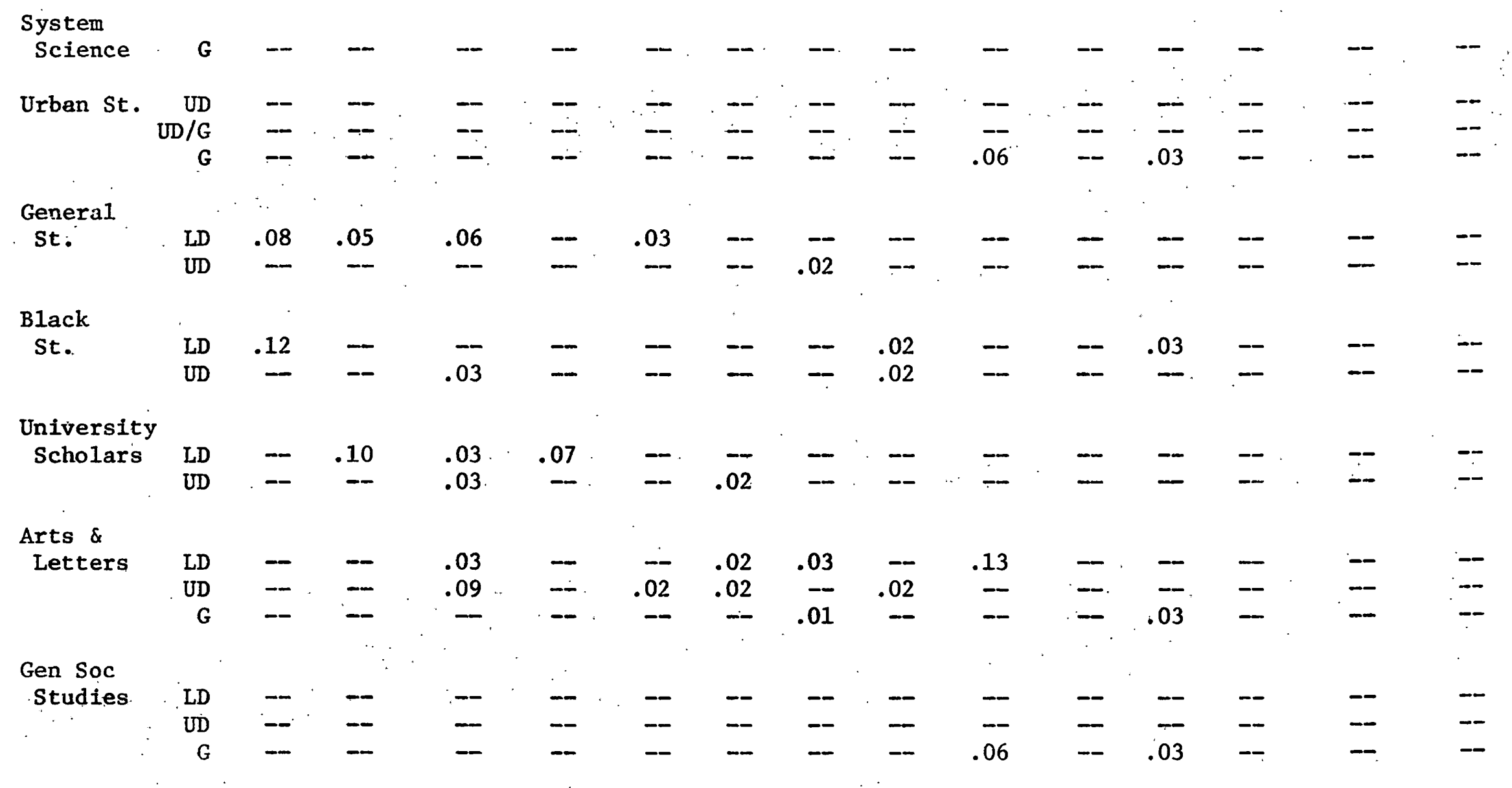


TABLE I (Continued)

\begin{tabular}{|c|c|c|c|c|c|c|c|c|c|c|c|c|c|c|c|}
\hline & & & & & & & & & & & & & & & \\
\hline & $\begin{array}{l}\text { LD } \\
\text { UD }\end{array}$ & $\begin{array}{r}14.01 \\
1.05\end{array}$ & $\begin{array}{r}13.78 \\
1.23\end{array}$ & $\begin{array}{l}8.31 \\
6.65\end{array}$ & $\begin{array}{l}7.59 \\
7.23\end{array}$ & $\begin{array}{r}4.90 \\
10.03\end{array}$ & $\begin{array}{r}4.04 \\
10.78\end{array}$ & $\begin{array}{r}2.06 \\
12.61\end{array}$ & $\begin{array}{r}1.69 \\
13.13\end{array}$ & $\begin{array}{l}1.03 \\
1.68\end{array}$ & $\begin{array}{r}.96 \\
1.86\end{array}$ & .31 & .31 & $\begin{array}{r}1.89 \\
10.53\end{array}$ & $\begin{array}{r}2.95 \\
10.13\end{array}$ \\
\hline & UD/G & - & - & .06 & - & .05 & .02 & .07 & .10 & 4.51 & 4.19 & 3.86 & 4.11 & 1.97 & 1.09 \\
\hline & G & - & .05 & .06 & .11 & .04 & .17 & .30 & .15 & 7.88 & 8.07 & 9.92 & 9.43 & .58 & .80 \\
\hline *Total & $\therefore$ & 15.06 & 15.06 & 15.08 & 14.93 & 15.02 & 15.01 & 15.04 & 15.07 & 15.10 & 15.05 & 15.05 & 15.02 & 14.97 & 14.97 \\
\hline
\end{tabular}

*Deviation from 15.00 due to rounding error. 
fall term, 1972 and fall term, 1973. For example, during fall term, 1972 the average FTE elementary education major at the freshman level took .27 credit hours in lower division and .08 credit hours in upper division art and architecture courses, .08 credit hours in lower division theater arts, .22 credit hours in lower division and .04 credit hours in upper division music, and 2.10 credit hours in lower division and .23 credit hours in upper division English. Total credit hours taken at all levels in all departments for each level total approximately 15, representing the credit hour load of the average FTE student.

Table II displays the average credit hours taken in education courses by the average FTE student in other major groups by student level within each major and by course level in education. For example, during fal1 term 1972, in upper division education courses the average FTE non admitted freshman took .02 credit hours, a sophomore took .05 credit hours, a junior took .16 credit hours, a senior took .72 credit hours and a graduate took .32 credit hours.

For the purpose of analysis, an. ICLM was calculated for elementary education majors at the freshman, sophmore, junior and senior levels, resulting in the average credit hours taken in each department by each student level for each year. Each student level average was then used as an observation of the credit hours taken in each department. The same calculation was applied to graduate students using MA/MS as one observation and graduate elementary education students as the second observation. 
TABLE II

AVERAGE HOURS TAKEN IN EDUCATION BY MAJOR GROUPS BY STUDENT LEVEL AND COURSE LEVEL

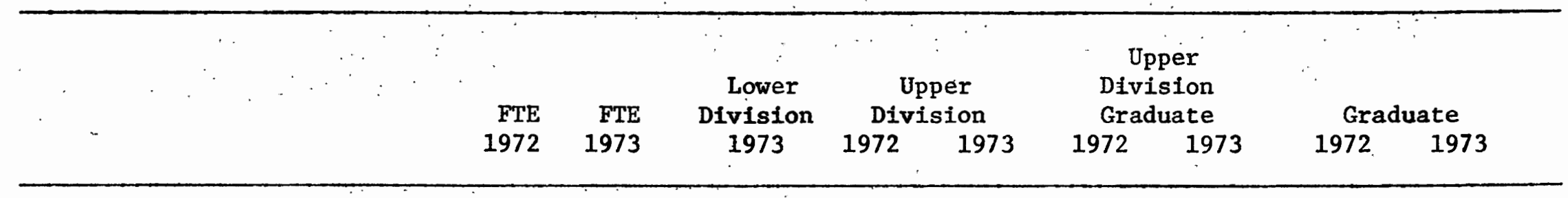

\section{Major/Level}

\section{Non Admitted}

\begin{tabular}{|c|c|c|c|c|c|c|c|c|c|}
\hline Freshman & 125 & 113 & - & .02 & .03 & - & - & - & .06 \\
\hline Sophomore & 120 & 105 & - & .05 & -- & - & 一 & - & -- \\
\hline Junior & 115 & 106 & -- & .16 & .49 & -- & - & -- & -- \\
\hline Senior & 116 & 123 & -- & .72 & .76 & .75 & .46 & .03 & - \\
\hline Graduate & 155 & 177 & - & .32 & .38 & 1.45 & 1.32 & 3.17 & 3.62 \\
\hline
\end{tabular}

General Studies - General

\section{Freshman \\ Sophomore \\ Junior \\ Senior \\ Graduate}

Business Administration

Freshman

Sophomore

$\begin{array}{lr}- & 96 \\ - & 61 \\ - & 63 \\ - & 59 \\ - & 4\end{array}$

$\begin{array}{ll}- & -- \\ -- & -- \\ -05 & -- \\ -- & - \\ - & -\end{array}$

$\begin{array}{ll}.03 & - \\ -- & - \\ -- & - \\ .46 & - \\ -- & -\end{array}$

--
--
-
-75

--
--
--
--

--
--
-- 
TABLE II (Continued)

Junior

Senior

Graduate

Undeclared

\section{Freshman}

Sophomore

Junior

Senior

Graduate

Business Education

\section{Freshman \\ Sophomore \\ Junior \\ Senior \\ Graduate}

\section{Elementary Education}

\section{Freshman \\ Sophomore \\ Junior \\ Senior. \\ Graduate}

Equivalency Program

$397 \quad 377$

$317 \quad 301$

$108 \quad 134$

$\begin{array}{llll}-- & - & - & -- \\ .01 & .05 & .03 & -- \\ -- & .03 & -- & --\end{array}$

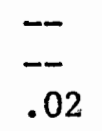

$\overline{-} \quad--$

.04

$\begin{array}{rrlllllll}241 & 252 & .01 & .01 & .02 & - & - & - & .03 \\ 68 & 77 & -- & .31 & .08 & - & - & - & -- \\ 18 & 34 & -- & -- & - & - & -- & - & - \\ 9 & 10 & -- & -- & .90 & - & -- & - & - \\ 9 & 36 & -- & -- & .33 & 1.33 & .47 & 2.67 & .83\end{array}$

$\begin{array}{rrrrrrrrr}6 & 6 & - & - & - & - & -- & -- & - \\ 2 & 3 & -- & - & - & - & - & -- & - \\ 9 & 3 & -- & 2.00 & - & - & - & - & - \\ 12 & 7 & -- & 5.50 & 3.00 & - & - & - & - \\ 15 & 10 & -- & .20 & 1.20 & 1.53 & 2.70 & 2.00 & .60\end{array}$

$78 \quad 63$

105

181

182

47
.14

.04

.04

.02
1.29

4.10

9.46

1.02
.11

1.32

4.37

10.13

1.47
2.
$--$
$-.05$

$.06: .11$

$.04 \quad .17$

$\begin{array}{ll}.04 & .10\end{array}$

$\begin{array}{ll}.21 & 6.88\end{array}$

Graduate 
TABLE II (Continued)

Health Education

Freshman

Sophomore

Junior

Senior

Graduate

Health and Physical

Education

Freshman

Sophomore

Junior

Senior

Graduate

\section{Physical Education}

Freshman

Sophomore

Junior

Senior

Graduate

Art

Freshman

Sophomore

Junior

Senior

Graduate

$\begin{array}{rrr}4 & 3 & - \\ 2 & 7 & - \\ 4 & 5 & - \\ 6 & 6 & - \\ - & - & -\end{array}$

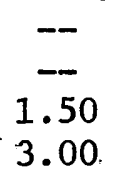

--
--
1.50

$-$

$\begin{array}{lll}- & - & - \\ -- & - & - \\ -- & - & - \\ - & - & - \\ - & - & -\end{array}$

19
23
46
66
12

$\begin{aligned} 14 & - \\ 24 & - \\ 25 & - \\ 60 & -- \\ 6 & -\end{aligned}$

.26

$$
1.04
$$

5.30

--
.25
.24
5.25
.50

--
--
--
.05
2.75

--
--
--
2.50

$\begin{array}{ll}-- & -- \\ -- & - \\ -- & -- \\ .09 & -- \\ .25 & --\end{array}$

$33 \quad 29$

26

25

12

29
19

22

13$$
\overline{-}
$$

$\begin{array}{lc}-- & - \\ \overline{-} & . \\ -- & .36 \\ -- & --\end{array}$

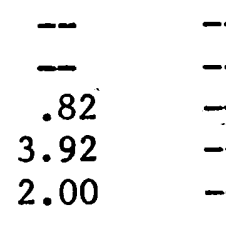

--
$\overline{-}$
-

$\begin{array}{ccc}\overline{-} & \overline{-} & \overline{-} \\ \overline{-} & \overline{-} & .16 \\ \overline{-} & \overline{-} & \overline{--} \\ 2.00 & -- & 1.00\end{array}$

$\begin{array}{rr}116 & 79 \\ 82 & 74 \\ 83 & 80 \\ 85 & 78 \\ 15 & 14\end{array}$

\begin{tabular}{lll}
-- & - & - \\
-- & - & -- \\
-- & -- & -- \\
$-\overline{1.29}$ & - & - \\
\hline 60 & .43
\end{tabular}

$\stackrel{N}{\infty}$ 
TABLE II (Continued)

English

Freshman

Sophomore

Junior

Senior

Graduate

48
81
97
96
60

Fcreign Language

Freshman
Sophomore
Junior

Senior

Graduate

\section{French}

Freshman

Sophomore

Junior

Senior

Graduate

German

Freshman

Sophomore

Junior

Senior

Graduate

24
15
11
7
5

$\begin{array}{ll}2 & 4 \\ 4 & 8 \\ 7 & 4 \\ 8 & 8 \\ 3 & 2\end{array}$

$\equiv$

$$
\underset{\substack{3.00 \\ 5.00}}{1.0}
$$$$
\begin{array}{ccc}
- & - & - \\
-- & - & - \\
-- & -- & - \\
1.50 & .38 & - \\
-- & -- & 1.50
\end{array}
$$$$
\begin{array}{cc}
-- & - \\
-- & -- \\
-- & - \\
-- & -- \\
1.00 & : 1.50
\end{array}
$$

$\begin{array}{rr}10 & 6 \\ 7 & 4 \\ 2 & 6 \\ 7 & 7 \\ 3 & -\end{array}$

$\begin{array}{ccc}-- & - & - \\ -- & -- & - \\ .50 & -- & - \\ 2.14 & - & - \\ -- & 2.00 & -\end{array}$

$\begin{array}{ll}-- & -- \\ -- & - \\ -- & - \\ -- & -\end{array}$ 
TABLE II (Continued)

Spanish

\begin{tabular}{|c|c|c|c|c|c|c|c|c|c|}
\hline Freshman & 10 & 4 & .75 & - & - & -- & -- & -- & - \\
\hline Sophomore & 11 & 7 & - & - & .43 & -- & - & - & - \\
\hline Junior & 8 & 7 & -- & .75 & 2.14 & -- & - & $\because-$ & - \\
\hline Senior & 7. & 8 & - & 2.14 & 5.25 & -- & -- & - & - \\
\hline Graduate. & 2 & 4 & -- & -- & - & -- & 2.25 & - & \\
\hline
\end{tabular}

Romance Languages

Freshman

Sophomore

Junior

Senior

Graduate

General Studies -- Arts and Letters

\section{Freshman \\ Sophomore \\ Junior \\ Senior}

Graduate

Speech

\section{Freshman}

Sophomore

Junior

Senior

Graduate

$\begin{array}{rllclllll}10 & 4 & -- & -- & - & -- & -- & -- & -- \\ 11 & 7 & -- & -- & -- & -- & -- & -- & - \\ 8 & 7 & -- & 2.00 & -- & -- & -- & -- & - \\ 7 & 8 & -- & -- & - & - & -- & -- & - \\ 2 & 4 & -- & 15.00 & -- & -- & -- & -- & --\end{array}$

$\begin{array}{rrrrrrrrr}87 & 70 & -- & - & - & - & - & -- & - \\ 50 & 40 & - & -- & .05 & -- & -- & -- & -- \\ 59 & 28 & -- & .15 & .11 & - & -- & .05 & - \\ 61 & 29 & -- & -- & .21 & -- & - & -- & - \\ 4 & 3 & -- & -- & -- & .75 & 2.00 & 3.00 & .00\end{array}$

$\begin{array}{cc}-- & 12 \\ -- & 23 \\ -- & 35 \\ -- & 42 \\ 12 & 12\end{array}$

$\begin{array}{ll}-- & - \\ -- & -- \\ -- & -- \\ -- & -- \\ -- & .25\end{array}$

$\begin{array}{ccc}-- & -- & -- \\ .09 & -- & - \\ 1.29 & -- & - \\ 2.63 & -- & - \\ -- & .50 & --\end{array}$

$\begin{array}{ll}-- & -- \\ -- & -- \\ -- & -- \\ -- & - \\ .50 & .25\end{array}$ 
TABLE II (Continued)

Pre-Journalism

\section{Freshman \\ Sophomore \\ Junior \\ Senior \\ Grâduate}

Speech and Hearing

\section{Graduate}

Music

Freshman

Sophomore

Junior

Senior

Graduate

\section{Philosophy}

Freshman

Sophomore

Junior

Senior

Graduate

Theater Arts

Freshman

Sophomore

$\begin{array}{cccccccccc}21 & 27 & .11 & -- & -- & - & -- & - & - \\ 23 & 14 & -- & - & - & - & - & - & - \\ 6 & 3 & - & - & - & - & - & - & - \\ 3 & 2 & - & - & - & - & - & - & - \\ - & 1 & - & -- & - & -- & - & -- & -\end{array}$

58
31
28
22
9

$\begin{array}{rrrrrrrr}67 & -- & - & -- & -- & -- & -- & -- \\ 34 & -- & .10 & -- & - & -- & -- & -- \\ 26 & -- & 1.07 & .12 & - & -- & -- & - \\ 36 & -- & 1.91 & 2.08 & .14 & -- & -- & - \\ 8 & -- & 1.89 & .38 & 2.33 & 3.00 & .33 & .75\end{array}$

13
15
22

7
14
19
15
-

$\underline{-} \equiv$

$\begin{array}{ll}-- & - \\ -- & - \\ - & - \\ -40 & -\end{array}$

$+-$

$\begin{array}{ll}- & - \\ -- & - \\ -- & - \\ -- & - \\ - & -\end{array}$

16

16
$-$

$--$
$-$
$=$
$--$
$--$ 
TABLE II (Continued)

Junior
Senior
Graduate

Speech and Theater Arts

Freshman

Sophomore

Junior

Senior

Graduate

\section{Biology}

Freshman

Sophomore

Junior

Senior

Graduate

Chemistry

Freshman

Sophomore

Junior

Senior

Graduate

Pre-Dentistry

Freshman

Sophomore $\begin{array}{rrrrrrrrr}- & 11 & -- & - & - & - & -- & -- & - \\ -- & 6 & -- & -- & .50 & - & - & -- & - \\ 9 & 13 & -- & -- & .92 & .33 & .46 & 2.11 & - \\ & & & - & & & & & \end{array}$

$\begin{array}{rrrrrrrrr}51 & 8 & -- & - & - & - & -- & - & - \\ 48 & 10 & -- & -- & - & -- & -- & -- & - \\ 48 & 5 & -- & .50 & -- & -- & -- & -- & - \\ 39 & 3 & -- & 1.67 & -- & - & -- & .08 & - \\ 5 & 1 & -- & 1.80 & -- & -- & - & -- & 3.00\end{array}$

$\begin{array}{lllllllll}84 & 44 & - & - & - & - & - & -- & - \\ 76 & 66 & - & -- & -- & -- & - & -- & -- \\ 86 & 86 & -- & -- & .14 & -- & -- & -- & - \\ 62 & 69 & -- & .19 & .09 & -- & -- & - & - \\ 48 & 42 & -- & .50 & .29 & .31 & .29 & -- & .14\end{array}$

\begin{tabular}{|c|c|c|c|c|c|c|c|c|}
\hline 16 & 23 & -- & -- & - & -- & $\therefore$ & - & - \\
\hline 27 & 21 & -- & -- & - & - & -7 & - & - \\
\hline 20 & 17 & -- & .75 & .18 & - & $\ldots$ & - & - \\
\hline 25 & 23 & -- & .36 & .91 & - & - & - & \\
\hline 12 & 8 & -- & -- & -- & .25 & .38 & .50 & $\cdots$ \\
\hline
\end{tabular}

$40 \quad 31$

$29 \quad 18$

$--\quad=$

$--\quad-$

$-$

$--$ 
TABLE II (Continued)

\begin{tabular}{|c|c|c|c|c|c|c|c|c|c|}
\hline Junior & 29 & 21 & -- & -- & - & -- & -- & - & -- \\
\hline Senior & 13 & 18 & -- & .46 & - & -- & -- & - & - \\
\hline Graduate & 8 & 11 & -- & -- & - & -- & -- & - & -- \\
\hline
\end{tabular}

Earth Science

Freshman

Sophomore

- Junior

Senior

Graduate

$\begin{array}{rr}11 & 11 \\ 17 & 19 \\ 27 & 26 \\ 14 & 18 \\ 3 & 7\end{array}$

$\overline{-}$

$-$

$\begin{array}{lllll}-- & -- & -- & -- & - \\ -- & -- & -- & -- & -- \\ -- & -- & -- & -- & -- \\ -- & - & -- & -- & -- \\ .86 & -- & 1.71 & -- & --\end{array}$

Geology

Freshman

Sophomore

Junior

Senior

Graduate

\begin{tabular}{|c|c|c|c|c|c|c|c|c|}
\hline- & -- & - & - & - & -- & - & -- & -- \\
\hline 1 & -- & -- & - & - & - & - & -- & -- \\
\hline & $=$ & - & - & -- & - & - & -- & \\
\hline & - & - & 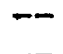 & $\overline{3}$ & $\overline{16}$ & $\overline{-}$ & $\overline{-}$ & - \\
\hline
\end{tabular}

General Studies -- Science

Freshman

Sophomore

Junior

Senior

Graduate

Pre Home-Economics

Freshman

Sophomore

$\begin{array}{rrrrrrrrr}26 & 44 & - & -- & -- & -- & - & - & - \\ 15 & 18 & -- & -- & .17 & - & -- & - & - \\ 18 & 21 & -- & -- & - & - & - & - & - \\ 38 & 26 & -- & .79 & 1.50 & -- & - & - & - \\ 7 & 8 & - & -- & - & .86 & 1.50 & -- & --\end{array}$

$\begin{array}{llllllllll}8 & 1 & - & - & - & - & - & - & - & \omega \\ 6 & 2 & -- & 1.50 & - & - & - & -- & -- & \omega\end{array}$ 
TABLE II (Continued)

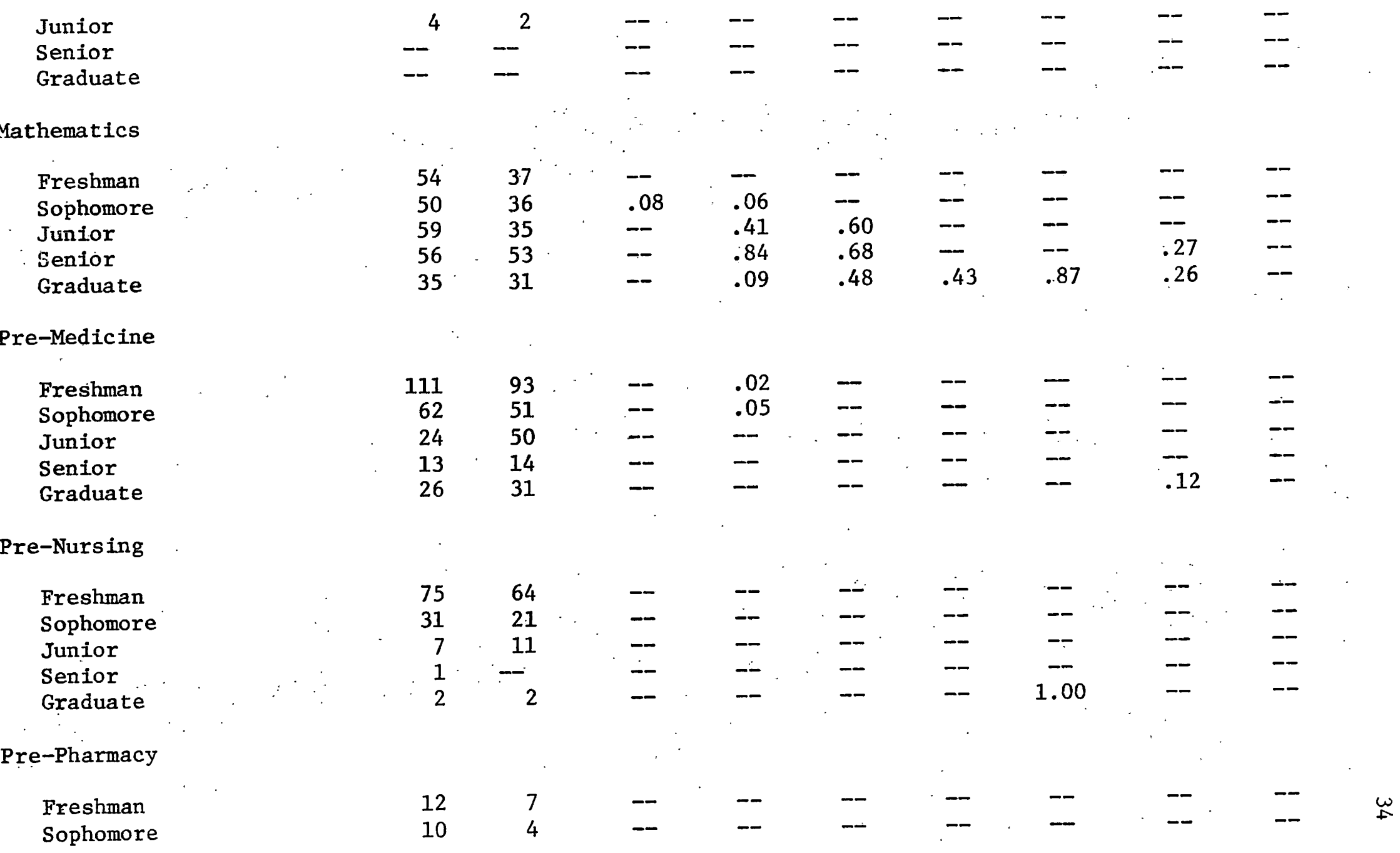


Junior

Senior

Graduate

Physics

Freshman

Sophomore

Junior

Senior

Graduate

Anthropology

Freshman

Sophomore

Junior

Senior

Graduate

Economics

Freshman

Sophomore

Junior

Senior

Graduate

eneral Studies - Social Science

Freshman

TABLE II (Continued)

$\begin{array}{lllllllll}-- & 2 & -- & -- & -- & -- & -- & -- & -- \\ -- & -- & -- & -- & - & -- & -- & -- & - \\ -- & -- & -- & -- & 3.00 & -- & - & -- & -\end{array}$

$\begin{array}{rrrrrrrrr}19 & 14 & -- & -- & -- & - & -- & -- & - \\ 15 & 10 & -- & -- & - & -- & - & -- & - \\ 10 & 3 & -- & -- & -- & -- & -- & -- & - \\ 8 & 10 & -- & - & .30 & -- & -- & -- & - \\ 5 & 5 & -- & -- & -- & 1.20 & -- & -- & --\end{array}$

$\begin{array}{lllllllll}15 & 8 & - & -- & -- & -- & -- & -- & - \\ 29 & 20 & - & -- & .15 & -- & -- & -- & - \\ 38 & 28 & -- & .08 & - & -- & -- & -- & - \\ 24 & 27 & -- & -- & .22 & -- & -- & -- & - \\ 18 & 18 & -- & -- & -- & -- & -- & -- & --\end{array}$

\begin{tabular}{|c|c|c|c|c|c|c|c|c|}
\hline 14 & 15 & -- & -- & -- & -- & - & -- & $\div$ \\
\hline 27 & 15 & - & -- & -- & - & -- & -- & -- \\
\hline 42 & 24 & -- & -- & - & -- & -- & - & - \\
\hline 25 & 23 & $-\infty$ & -- & -- & -- & -- & -- & \\
\hline 15 & 15 & -- & - & .20 & -- & -- & - & \\
\hline
\end{tabular}

$50 \quad 44$ 
TABLE II (Continued)

$\begin{array}{llllllllll}\text { Sophomore } & 34 & 42 & -- & .09 & .07 & - & -- & -- & -- \\ \text { Junior } & 82 & 57 & -- & .44 & .42 & -- & -- & - & .11 \\ \text { Senior } & 75 & 66 & -- & .83 & 1.27 & -- & -- & --. & .14 \\ \text { Graduate } & 25 & 18 & -- & 2.88 & .1 .00 & 2.04 & 2.00 & 1.60 & .83\end{array}$

Geography

Freshman

Sophomore

Junior

Senior

Graduate

$\begin{array}{rrrllllll}6 & 3 & -- & - & - & -- & -- & -- & - \\ 12 & 6 & -- & -- & - & -- & -- & - & - \\ 26 & 16 & - & .23 & -- & -- & -- & - & - \\ 37 & 25 & -- & -- & -- & - & -- & .08 & - \\ 11 & 12 & -- & -- & .50 & -- & .25 & .55 & .25\end{array}$

History

Freshman

Sophomore.

Junior

Senior

Graduate

$\begin{array}{rrrrrrrrr}33 & 30 & -- & -- & -- & -- & - & -- & -- \\ 52 & 33 & - & .06 & -- & - & - & -- & - \\ 91 & 59 & - & .26 & .10 & -- & - & .07 & - \\ 99 & 74 & -- & 1.45 & 1.66 & -- & -- & -- & .20 \\ 37 & 31 & -- & .51 & .29 & .16 & .19 & .24 & .10\end{array}$

Law Enforcement

Freshman

Sophomore

Junior

Senior

Graduate

Political Science

Freshman

$\begin{array}{lllllll}-- & - & - & - & -- & -- & -- \\ -- & -- & -- & -- & -- & -- & -- \\ -- & -- & -- & -- & -- & -- & -- \\ -- & -- & .56 & -- & -- & -- & -- \\ -- & -- & -- & -- & -- & -- & --\end{array}$


TABLE II (Continued)

Sophomore

Junior

Senior

Graduate

Psychology

Freshman

Sophomore

Junior

Senior

Graduate

Sociology

Freshman

Sophomore

Junior

Senior

Graduate

Social Work

Graduate

153

122

MA-MS Education

Graduate

63

88

26

$116 \quad 62$

$154 \quad 122$

$201 \quad 154$

$154 \quad 133$

$29 \quad 33$

$82 \quad 63$

$\begin{array}{rr}95 & 60 \\ 134 & 102\end{array}$

$97 \quad 78$

29

20

98

75

75

55 - $\quad .08$

$\overline{--}$

.03

.04

.36

--
.05
.10
--

$-$

.09

.12

.27

.35

$=$

.06

.05

.02

.02

.25

.10

.18

--

.09

.10

.15

.05

.08

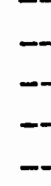

$-$

$--$

$--\quad-$

.07

.10

$-$

.61

.86

2.39

2.88

8.54

8.58 
To determine the demand on the School of Education by other major groups, an ICLM by major was calculated by the course level taken in education for each year. For this calculation, the total hours taken for each major at each level was divided by the total FTE for that particular major. For example, in fall term, 1972 the average FTE business education major took 1.98 credit hours in upper division education courses, .52 credit hours in upper division-graduate education courses and .68 credit hours in graduate education courses. Each of these levels was then used as an observation for analysis. Due to the capacity of the computer program, the number of different majors was limited to 45 . Student major groups not included in this analysis were those who did not place demands on the School of Education during the two terms under investigation. A list of the student major groups excluded and their FTE is shown in Table III. One other student major group was not subjected to analysis in this study. This major group is identified as equivalency program. These are students who have a baccalaureate degree and are only seeking a teaching certificate. However, it could not be ascertained whether they were seeking an elementary or secondary certificate, or whether this group was a combination of both groups. The course demands of this major are included in Table I, since they took a majority of their work in education courses.

To test the hypothesis that elementary education majors place equal demands on other academic departments outside education, both an analysis of variance and a Friedmen non-parametric analysis of variance were applied. The Friedman test was also used because it 
TABLE III

MAJOR GROUPS NOT INCLUDED IN STUDY

WITH TOTAL FTE ENROLLMENT FOR

FALI 1972 AND FALL 1973

Environmental Science

Systems Science

Urban Studies

Secretarlal Science

Applied Design

Architecture-Pre

Teaching English as a Secondary Language

Japanese

Modern Languages

Persian

Portugese

Russian

Interior Architecture

Fine Arts

Landscape Architecture

Pre-Agriculture

Applied Science

Pre-Dental

Pre-Food

Pre-Forestry

Pre-Med1cal Technology

Administration of Justice

Public Health

Pre-Veterinary M.D.

Middle East Studies

International Business

Pre-Law

Social Service Certificate

Urban Studies

Engineering

Total FTE Not Included
17

16

25

3

5

36

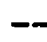

1

12

$--$

1

16

6

$--$

8

3

14

20

1

15

42

$-$

6
42

5

. 2

64

1

10

244

615
16

15

35

9

6

79

. 7

.

.

8

. 5

... 5

3

10

13

11

54

52

6

36

2

2

65

2

9

209

670 
could not be assumed that data were normally distributed. These two tests were also applied to data for graduate students in education as well as to data of the demands placed on the School of Education by other student major groups. A t-test was used to test the hypothesis that course demands were consistent over time for each of these groups.

\section{Results}

Results of the analysis of variance indicate a rejection $(p<.01)$ of the hypothesis that elementary education majors place equal demands on each of the academic departments outside education for both fall terms of 1972 and 1973. The hypothesis that graduate education students place equal demands on each of the academic departments outside education is rejected $(p<.01)$ for fall term, 1973, but not rejected for fall term, 1972. Also the hypothesis that other major groups place equal demands on the School of Education for coursework is rejected for fall term, 1973 ( $p<.01$ ) but not rejected for fall term, 1972 .

The Friedman non-parametric analysis of variance rejects the hypothesis that elementary education majors place equal demands on each of the academic departments outside education for both fall terms of 1972 and $1973(\mathrm{p}<.01)$. The hypothesis that graduate education students place equal demands on each of the academic departments outside education is rejected for both fall terms, 1972 and 1973 $(p<.05)$. Also the hypothesis that other major groups place equal demands on the School of Education for coursework is rejected for fall term, $1972(p<.01)$ and fall term, $1973(p<.05)$. 
The t-test applied to test stability over time for each of these three groups, elementary education majors, graduate education students and other major groups support the hypothesis that demands have remained consistent for elementary education majors and other major groups. For graduate students in' education only one department showed a significant difference. This difference occurred in the Political Science Department where graduate students in education place significantly greater $(\mathrm{p}<.01)$ demands during the fall term, 1972 than they did during the fall term, 1973. All other demands by graduate students in education on departments outside of education remain consistent over the two year period. Negative $\underline{t}$ values indicate that greater demand was placed during fall term 1973 than during fall term 1972. 
TABLE IV

ANALYSIS OF VARIANCE*

Group

F Calculated

Fal1 1972 Elementary Education Majors

10.24 significant at .01

Fa11 1972 Graduate Education Students

1.34

Fal1 1972 Other Major Groups in Education

1.40

Fall 1973 Elementary Education Majors

9.16 significant at .01

Fal1 1973 Graduate Education Students

9.50 significant at .01

Fal1 1973 0ther Major Groups in Education

1.62 significant at .01

FRIEDMAN NON-PARAMETRIC ANALYSIS OF VARIANCE

Group

$\chi^{2}$. Calculated

Fal1 1972 Elementary Education Majors

126.40 significant at .01

Fal1 1972 Graduate Education Students

53.80 significant at .05

Fal1 1972 other Major Groups in Education

76.89 significant at .01

Fal1 1973 Elementary Education Majors

130.54 significant at .01

Fa11 1973 Graduate Education Students

55.80 significant at .05

Fal1 1973 Other Major Groups in Education

64.07. significant at .05

*ANOVA tables are presented in Appendix A 
TABLE V

CALCULATIONS OF $t$ TESTS FOR ELEMENTARY EDUCATION MAJORS AND GRADUATE

EDUCATION SIUDENTS

Department

Education Majors

Graduate Education t-Calculated

t-Calculated

Art and Architecture

.50

.41

Theater Arts

.00

.54

Music

$-.50$

.00

English

$-.03$

$-2.04$

Speech

$-.16$

.85

Foreign Language

.16

1.05

Journalism

1.88

1.38

Psychology

.53

.02

Philosophy

$-.39$

.00

Anthropology.

$-.29$

.92

Economics

$-.72$

Geography

1.18

$-1.39$

History

.53

Political Science $\quad-.41$

.36

$-.33$

Sociology

$-.86$

$7.50 *$

Administration of Justice

1.25

Applied Science

$-.93$

1.00

Biology

$-.18$

$-.40$

.00

.64

.09

Mathematics

.55

Chemistry

1.57

Physics

Earth Science

$-.72$

Public Health

Accounting

Marketing

Management

Finance Law

$-1.00$

1.42

$-4.00$

Business Education

.00

$-.45$

.42

.49

.00

1.00

$-1.67$

.00

.00

.00

.00

.93

1.00

$-.09$

$-1.00$

Business Administration

.00

.00 
TABLE V (Continued)

Health

Physical Education

Social Work

System Science.

Urban Studies.

General Studies

Black Studies

University Scholars

Arts and Letters

General Social Studies
.43

$-.46$

1.00

.00

.00

1.88

.91

$-1.19$

1.07

.00
$-1.00$

$-.62$

$-.10$

.00

3.00

.00

1.00

.00

1.60

3.00

\section{TABLE VI}

CALCULATION OF $\cdot t$-TESTS FOR OTHER

MAJOR GROUPS ON EDUCATION

t-Calculated

Non-Admitted

General Studies - General

Business Administration

Undeclared

Business Education

Health Education

Health and Physical Education

Physical Education

Art

English

Foreign Language

French

German

Spanish

Romance Languages

General Studies Arts and Letters

Speech
.15

$-1.06$

.66

.07

.97

.90

.24

$-.66$

.02

.17

$-.01$

1.05

.47

$-.90$

1.20

.00

1.04 
TABLE VI (Continued)

$\begin{array}{lr}\text { Speech and Hearing } & .02 \\ \text { Music } & .53 \\ \text { Philosophy } & -.85 \\ \text { Theater Arts. } & 1.42 \\ \text { Speech and Theater Arts } & 1.04 \\ \text { Biology } & .19 \\ \text { Chemistry } & .41 \\ \text { Pre-Dentistry } & 1.20 \\ \text { Earth Science } & .03 \\ \text { Geology Studies - Science } & .50 \\ \text { General } & .03 \\ \text { Pre-Home Economics } & -.85 \\ \text { Mathematics } & .12 \\ \text { Pre-Medicine } & 2.07 \\ \text { Pre-Nursing } & -.85 \\ \text { Pre-Pharmacy } & -.85 \\ \text { Physics } & .52 \\ \text { Anthropology } & -.58 \\ \text { Economics } & -.85 \\ \text { General Studies - Social Science } & .58 \\ \text { Geography } & .19 \\ \text { History } & .21 \\ \text { Law Enforcement. } & -.85 \\ \text { Political Sclence } & .72 \\ \text { Psychology } & -.03 \\ \text { Sociology } & .04 \\ \text { Social Work } & 1.20 \\ \text { Pre-Journalism } & .00\end{array}$


An examination of the extent of the course demands placed on other academic departments by both elementary education majors and by graduate students in education follows. Also an examination is made of the course demands placed by other major groups on the School of Education.

Elementary Education Majors

Application of both the analysis of variance and the Friedman tests found that elementary education majors did not distribute their course demands equally on the other academic departments during either fall term. The greatest course demands were made on the English, Psychology and General Science Departments, with somewhat less but consistently high demands on the Mathematics, Speech, History and Music Departments.

These course demands were to be expected in that there are required courses for elementary education majors in all these departments except for history. While other social sciences could be taken to fulfill university and School of Education requirements, education majors seemed to prefer history and took both lower and upper division courses in this department. Sociology was a second choice with geography a third, anthropology a fourth and political science a fifth choice. Elementary education majors placed little demand on 
the Departments of Economics or Administration of Justice. The reason for this course taking behavior of these students could be any one or more of the following: student preferences due to interest in the courses, the time of day the courses are offered, adviser suggestions, or some notion of the types of social sciences taught in the elementary school based on the student's own recollection of their elementary social science curriculum.

In the sciences, the greatest demand was placed on the General Sclence Department with a concentration at the lower division level and with some demand on upper division and upper division graduate level. The lower division general science courses have been recommended for elementary education majors to fulfill the requirement of laboratory sciences. These general science courses are offered only for non-sclence majors. Data seemed to Indicate that some elementary education majors also took courses in addition to the recommended lower division courses with some course demands at the upper division and upper division graduate level in this department. Some elementary education majors opt to take their biological laboratory science in the Blology Department with course demands placed at both the lower division and upper division level. Course demands were also made on the Chemistry and Earth Sclence Departments. The course demands on the Chemistry Department were all at the lower division level while the Earth Science Department has both lower division and upper division demands. In mathematics, the greatest demand is at the lower division level. This coinciäes with the lower division mathematics requirement for all elementary education majors. Upper division course 
demand on the Mathematics Department was small. Elementary education majors placed few demands on the Departments of Applied Science and Physics. Elementary education majors do not seem to be greatly science orlented.: Course demands indicate that little work was done in this area other than at the required level with most sclence work done at the lower division level.

In the Arts and Letters, the course demands on the English, Speech, Music and Art Departments were anticlpated due to required. courses in these departments. However, the course requirements in speech, music and art have been about the same. One course in each area has been required. Yet, elementary education majors placed greater demand on music and speech than they did on art. Course demands on the Music and Art Departments seem to be fairly evenly divided between. lower division and upper division work, whereas demands in the Speech Department were mostly at the lower division level. The course demand on the Speech Department as shown is actually somewhat inflated due to the fact that many elementary education majors took a five credit hour lower division course to fulfill the speech requirement rather than the three hour course. The demand on the Philosophy Department has also been quite high, especially at the lower division level. This reflects that philosophy couxses have been a prerequisite for the Philosophy of Education course which was required. There has also been some demand on the Foreign Language Department, mostly at the lower division level. Elementary education majors placed few demands on Departmenț of Theater Arts and Journalism.

Course demands on the School of Business by elementary education 
majors have been small. No demand was made on the departments of Marketing or Business Administration. Most courses were taken in the Department of Business Education at the lower division level. This low demand is to be anticipated and is purely an indication of student interest.

In the area of health and physical education, the course demands were somewhat an indication of the university requirements of five physical education credits and one health credit. However, most are one credit hour courses and therefore, the course demands relative to other departments are understated. Also veterans and students over the age of 25 do not have to meet these requirements. Both health and physical education had the greatest course demands placed at the lower division level with some demand at the upper division level.

Elementary education majors placed few course demands on the Department of Social Work, General Studies, Black Studies, University Scholars and Arts and Letters. No demand was placed on the Department of General Social Studies for either year. The reasons for this low demand were probably due to the limited course offerings of these departments, specialized nature of the program and student preferences. No demand was placed on the Departments of Systems Sclence and Urban Studies which is to be expected since these are doctoral departments. As demonstrated by the $\underline{t}-t e s t$, the course demands of elementary education majors have remained consistent during these two terms. 
Graduate Education Students

The analysis of varlance test did not reveal any significant

difference in the demands placed by graduate education students for fall term, 1972, but did find a significant difference for fall term, 1973. The Friedman test found significant differences for both fall terms. Based on the non-parametric assumption, graduate education students did not distribute their course demands equally on other academic departments.

Course taking behavior of graduate education students is strictly a function of student preference since there are no required courses outside of education courses. Graduate education students placed the greatest course demands on the Psychology Department.: While there was some demand at the lower division and upper division level, most demand was at the upper division-graduate and graduate levels. other departments on which there were the greatest course demands included Speech, Sociology and English.

In the area of arts and letters the course demands on the English and Speech Departments were consistently the greatest with courses being taken at all 1eve1s. The greatest demand was at the upper division-graduate and graduate levels. The Departments of Music and Art and Architecture also received some course demands. However, the demand on art and architecture was at the lower division, upper division and upper division-graduate level while the Music Department also had demands at the graduate level. Demands on the Foreign Language Department were greater for fall, 1972 than for fall, 1973. 
but the difference was not significant and all demands were at either the lower division or upper division level. Little demand was placed on the Departments of Theater Arts, Philosophy and Journallsm. The course demands of graduate education students in the departments in arts and letters are quite similar to the course demands of elementary education majors.

Next to the great demand placed on the Psychology Department, other social science departments where graduate students in education placed course demands were History and Sociology followed by Geography. In both the History and Soclology Departments, the majority of course demands were at the upper division-graduate or graduate level. In the Geography Department, course demands were at elther the lower division or upper division-graduate level. The Political Science Department had some demand on the upper division-graduate and graduate level for fall, 1972, but none in fall, 1973. This was the only department where the t-test indicated a significant difference in the demand over the two terms. There was little demand on the Departments of Anthropology, Economics and Administration of Justice. Again, the course demands of graduate education students in the social sciences were quite similar to the course demands of elementary education majors.

The Mathematics Department recelved the greatest course demands in the sciences for graduate education students. However, the majority of this demand was at the lower division level. It could be speculated that these graduate students were refreshing their mathematics skills, since they could not use lower division courses for graduate credit. There was also some demand on the General Science Department, again, 
mostly at the lower division level. The Earth Science Department recelved course demands at the graduate level in 1972 and at the lower division, upper division and upper division-graduate level in 1973. Course demands on the Blology and Physics Departments were low and there were no demands placed on the Departments of Chemistry, Applied Sclence and Public Health for either term. Graduate education students do not seem to be any more science oriented than their undergraduate counterparts. Within the School of Business, no demands were placed on the Departments of Accounting, Marketing, Management or Business Administration. Few demands were placed on the Department of Finance Law and Business Education by graduate elementary education students, but none by MA/MS students.

The course demands on the Physical Education Department were falrly high with the majority at the graduate level. There was little demand on the Health Department, and then only at the graduate level for fall, 1973.

The School of Social Work recelved some demand at the graduate level, mostly from graduate elementary students. Few demands were also placed on the Departments of Urban Studies, Black Studies, Arts and Letters, and General Soclal Studies. No course demands were placed on the Departments of Systems Science, General studies and - University Scholars by graduate education' students.

The course demands of graduate education students were very similar to the course demands of elementary education majors. It could be speculated that the foundation for undergraduate coursework stimulated an interest in doing further work in these academic areas. 
A concentration of course demands for both elementary education majors and graduate education students in such Departments as Psychology, English, Speech, H1story, Soclology, Art and Archftecture and Music seem to support this hypothesis. Also the small course demands on the Departments of Theater Arts, Journalism, Economics, Administration of Justice; Applied Sclence, Physlcs, Public Health, Social Work, Systems Science and Business courses demonstrate that both elementary education majors and graduate education students tend to avold taking courses in these departments.

\section{Course Demands of Other Major Groups on Education}

The analysis of variance did not find a significant difference in the course demands placed on the School of Education by other major groups for the fall term, 1972, but did find a significant difference for fall term, 1973. The Friedman test found a significant difference for both fall term, 1972 and fall term, 1973. Based on a nonparametric assumption; other major groups did not place equal demands on the School of Education for coursework. The t-test found that course demands of other major groups were consistent over the two terms.

One lower division course was offered by the School of Education in the fall of 1973. This course was Introduction to Early Childhood Education. All other courses were at the upper division, upper division-graduate and graduate levels.

Major groups that placed consistently high course demands on the School of Education for both terms, included business education, 
health and physical education, speech and hearing, and non admitted students. Foreign language majors in Spanish, French and German also placed great course demands on the School of Education.

The demand placed by business education majors is not surprising. These majors are, for the most part, committed to becoming secondary teachers. It would also seem that most health and physical education majors are also planning to teach at the secondary level, as indicated by their course demands on the School of Education. Speech and hearing majors are usually interested in obtaining a certificate as speech therapists in the public schools and therefore, need to take education courses. The course demands of majors in the foreign languages for which there is a possibility of certification indicate that many of these majors also plan to teach at the secondary level. The absence of course demands by majors in other forelgn languages support this theory.

The great demand placed on the School of Education by non admitted. majors is signiflcant. A non admitted major is one who is taking six credit hours or less and therefore, does not need to be formally admitted to the university. The course demands this major group placed at the senior and graduate level were especially high. It is difficult to define the population of this major group. However, from their course demands on the School of Education, it could be supposed that many of them were either taking a course or two in preparation for teaching or are teachers and were taking additional education courses on a part time basis. 
The General Studies-Social Science majors placed greater course demands on the School of Education than other social science majors such as history, political science, psychology and sociology. This reflects the certification requirements for social science teachers at the secondary. level. Social science teachers must have course work in many of the social sciences. General studies-Social Science is a recommended major for someone who plans on teaching at the secondary leve1.

Other major groups in the area of arts and letters that placed falrly heavy course demands on the School of Education were English, music, art, speech, speech and theater arts, theater arts, and general studies-arts and letters. Majors in pre-journalism and philosophy placed few course demands on the School of Education. This is to be expected since journalism is a minor teaching field in secondary education at Portland State University and there is no certification program at the secondary level for philosophy.

of all the major groups in the sciences, mathematics majors placed the greatest course demands on the School of Education. This seems to indicate that many mathematics majors intend to become secondary teachers. Biology, chemistry and earth science majors placed a somewhat lower demand on the School of Education: Other than the pre-professional majors in the sciences such as pre-home economics, pre-medicine, pre-nursing and pre-pharmacy, the demands placed by the geology and physics majors were low. The demand that the preprofessional majors placed on the School of Education was sporadic and light and yet interesting. Education courses are not a part 
of. their regular program, so that the demands these groups place on the School of Education are attributable to student preferences alone. As expected, major groups for which teacher certification is available placed the greatest course demands on the School of Education. Pre-professional and other majors for which there is no direct teacher education programs placed little demand on the School of Education. 


\title{
CHAPTER V
}

\author{
SUMMARY AND IMPLICATIONS
}

This study has examined the function of the School of Education within and throughout the university by means of the course demands placed by elementary education majors and graduate education students on the other academic departments as well as the course demands placed on the School of Education by other major groups.

Statistical analysis of the course demands found that elementary education majors and graduate education students did not place equal demands on other academic departments. Also, other major groups did not place equal course demands on the School of Education. Course demands for these three groups have remained consistent, for the most part, between the fall term, 1972 and the fall term, 1973.

Elementary education majors placed the greatest course demands on departments in which there were required courses. Course demands placed on the History Department were, however, the exception. The course demands of graduate education students were similar to those of elementary education majors. Other major groups for which teacher certification is available placed the greatest course demands on the School of Education.

With some departments and their majors there is a strong interrelationship with the School of Education. This is demonstrated by the reciprocal demands placed on these departments by elementary 
education majors and graduate education students and by the demands their majors place on the School of Education. This is especially true for the Speech Department and their majors in the field of speech and hearing and speech. It is also true for the Health and Physical Education Department and their majors in health and physical education. There is a strong interrelationship between the social sciences and the School of Education with education majors placing heavy demands on the social sciences, especially psychology and history and General Social Science majors placing heavy demands on the School of Education. In the sciences, education majors place a greater demand on science departments than science majors place on the School of Education. Since the dissolution of the General Science Department and its absorption by the Biology and Chemistry Departments, it can be expected that the course demands by elementary education majors on the Biology and Chemistry Departments will increase in the future.

Within departments in arts and letters, foreign language majors in Spanish, German and French place demands on the School of Education, and elementary education majors and graduate students in education place demands on the Foreign Language Department. English majors place some demands on the School of Education and elementary education majors and graduate students in education place great demand on the English Department. In art and music, there are demands from education students and by major groups in those areas. However, the demand on the School of Education is greater by the Business Education majors than is the demand made on the Business Education Department or any 
other business department by elementary education majors. The reverse is true for the Philosophy Department where elementary education majors placed a high demand and a low demand was placed on the School of Education by philosophy majors.

New teacher education certification requirements may affect the course demands of elementary education majors in the future. From these new requirements, it can be expected that additional course demands will be made on the Departments of Art and Architecture and Music, since the requirements in these areas have risen from three to six credit hours. Also, Philosophy of Education is no longer a required course for certification and therefore a decrease in course demands of elementary education students on the Philosophy Department can be anticipated.

Graduate education students and elementary education majors place similar course demands on other academic departments. For example, both groups have placed high course demands on the Psychology Department and 1ow on the Economics Department. The exceptions to this are the high demands placed by elementary education majors on the Philosophy and General Science Departments and the low demands placed on these departments by graduate education students.

Further research is needed to determine specific reasons for the course taking behavior of elementary education majors, especially in the area of the social sciences. It would be helpful, for instance, to know why elementary education majors placed much greater demands on the History Department than they did on the Economics Department. Also, while the course demands of elementary education majors can, for 
the most part, be accounted for due to the requirements of the university and the School of Education, the course demands of graduate education students are not so easily anticipated, especially the lower division and upper division course demands that are made by this group. Research in this area would also be valuable. Advisers of elementary education majors should be aware that these majors placed few demands on such departments as Economics, Administration of Justice and Theater Arts. They could, therefore, encourage students to enroll in appropriate courses in these areas. The need for communication between the School of Education and other departments is demonstrated by the course demands made by. elementary education majors and graduate education students on departments and the course demands made on the School of Education by other major groups. While this need is greater in some areas than others, decisions made have far reaching implications for all. In some departments, courses that were appropriate for elementary education majors and graduate education students might be offered more often if assurances were made that there would be a substantial increase in enrollment. Also, the need for departments to offer methods courses in their specific areas during certain terms might be identified.

The importance of accurate coding for major groups by the Admissions office and the Registrar's office has been emphasized by the fact that equivalency program majors could not be defined for the purpose of examination. The recently implemented Student Information System (SIS) now has the capability of separating elementary 
equivalency students from secondary equivalency students. Also, previously there has been no method for identifying secondary education students except at the time of graduation. The SIS, however, is capable of carrying two majors. As a result of this study, in the future, secondary education students will have their second major identified as secondary education. This will permit the early identification of these majors and allow the School of Education and the university to make better predictions about enrollment patterns for this group.

While it is worthwhile to examine the course demands of student major groups by student and course level, it would be even more worthwhile to know excactly which courses were taken by each group. For example, the course demands placed on the History Department by elementary education majors were high. It would be helpful, as well as interesting, to know which history courses elementary education majors were taking.

Future.course demands of elementary education majors and graduate education students should be analyzed in view of the new teacher education requirements in order to ascertain if the course taking behavior of these groups, does, in fact change. The ICLM provides the tool for this analysis. It is now the responsibility of administrators to use it. 


\section{A SELECTED BIBLIOGRAPHY}

Adrian, William B. "Individual Experiences: PLANTRAN at the University of Denver." Let's End the Confusion About Simulation Models. Ed. Andrea Rubenstein. New York: Society for College and University Planning, September 1973, pp. 46-48.

Alkin, Marvin C. and James E. Bruno. "Systems Approaches to Educationa1 Planning." Social and Technical Change. Implication for Education. Ed. Philip K. Piete, et al. Eugene, Oregon: Center for the Advanced Study of Educational Administration, University of Oregon, 1970, pp. 191-245.

Andrew, Gary M. "Individual Experiences: CAMPUS at Colorado." Let's End the Confusion About Simulation Models. Ed. Andrea Rubenstein. New York: Society for College and University Planning, September 1973, pp. 39-41.

Burrows, J. H. Information Systems Overview. Bedford, Massachusetts: Mitre Corporation, June 1970.

Clark, David G.; et al. Introduction to the Resource Requirements Prediction Model 1.6 Technical Report No. $34 \mathrm{~A}$. Boulder, Colorado: Western Interstate Commission for Higher Education, October 1972.

Evans, John A. "Educational Management Information Systems: Progress and Prospectives." Social and Technical Change. Implication for Education. Ed. Philip K. Piele, et al. Eugene, Oregon: Center for the Advanced Study of Educational Administration, University of Oregon, 1970, pp. 246-333.

Evans, Walter Keith. Management Information Systems in Higher Education: The Man Machine Interface. unpublished doctoral dissertation. Untversity of Michigan, 1972.

Farmer, James. An Approach to Planning and Management Systems Implementation. California State Colleges, January 1971.

Haight, Michael. J. and Charles W. Manning. Induced Course Load Matrix Generator. Boulder; Colorado: Western Interstate Commission for Higher Education, August 1972.

Hopkins, David S. P. "On the Use of Large-Scale Simulation Models for University Planning." Review of Educational Research. 41, No. 5 (December 1971), $467-478$. 
Hopmann, Robert. "Individual Experiences: SEARCH at Eight Colleges." Let's End the Confusion About Simulation Models. Ed. Andrea Rubenstein. New York: Society for College and University Planning, September 1973, pp. 49-50.

Huff, Robert A. and Michael E. Young. A Blueprint for RRPM 1.6 Application. Boulder, Colorado: Western Interstate Commission for Higher Education, April 1973.

Huff, Robert A. and Michael E. Young. Profiles of Management Information Uses. A Report on How Twelve Institutions Have Utilized Data From NCHEMS Management Information Systems. Boulder, Colorado: Western Interstate Commission for Higher Education, May 1974.

Hussain, K. M. A Resource Requirements Prediction Mode1 (RRPM-1). Guide for the Project Manager. Technical Report 20. Boulder Colorado: Western Interstate Commission for Higher Education, October 1971.

Hussain, K. M. and James S. Martin, eds. A Resource Requirements Prediction Mode1 (RRPM-1). Report on the Pilot Studies. Technical Report 21. Boulder, Colorado: Western Interstate Commission for Higher Education, October 1971.

Hussain, K. M. and Thomas R. Mason. "Planning Models in Higher Education: A Comparison of CAMPUS and RRPM." Tomorrow's Imperatives Today. Ed. Robert G. Cope. Association for Institutional Research, Proceedings of the 13th Annual Forum, 1973, pp. 74-85.

Implementation of NCHEMS Planning and Management Tools at California State University, Fullerton. Boulder, Colorado: Western Interstate Commission for Higher Education, August 1972.

Jewett, Frank I., et al. The Feasibility of Analytic Models for Academic Planning: A Preliminary Analysis of Seven Quarters of Observations on the Induced Course Load Matrix. Los Angeles: Office Chancellor, California State Colleges, September 1970 .

Koski, Robert W. "Some Experiences with Computer Applications to Campus Planning." Institutional Research and Academic Outcomes. Ed. Cameron Fincher. Association for Institutional Research, Proceedings of the 8th Annual Forum, 1968, pp. 237-245. 
McNamara, James F. "Mathematical Programming Models in Educational Planning." Review of Educational Research. 41, No 5 (December 1971), 419-4 $\overline{46 .}$

Minter, John and Ben Lawrence, eds. Management Information Systems: Their Development and Use in the Administration of Higher Education. Boulder, Colorado: Western Interstate Commission for Higher Education, October 1969.

Resource Requirements Prediction Mode1 1.6 Reports, Technical Report 34 B. Boulder, Colorado: Western Interstate Commission for Higher, Education, 1973.

Sheehan, Bernard S. "Integrated University Management Information Systems." Integrated Research and Communication in Higher Education. Association for Institutional Research, Proceedings of the 10th Annual Forum, 1970, pp. 181-188.

Suslow, Sidney. "Using a Matrix of Coefficients as a Planning Tool." Design and Methodology in Institutional Research. Association for Institutional Research, Proceedings of the 5 th Annual Forum, 1965, pp. 133-138.

Weathersby, George. The Development and Application of a University Cost Simulation Model. unpublished monograph. University of California at Berkley, June 15, 1967. 
APPENDIX A

ANOVA SUMMARY TABLE ELEMENTARY.

EDUCATION MAJORS, FALL 1972

\begin{tabular}{lrrrrr}
\hline Source & & d.f. & SS & MS & F \\
\hline Treatment & $:$ & 39 & 26.2525 & 0.6731 & $10.24 *$ \\
Error & $\frac{117}{156}$ & $\frac{7.6972}{33.9497}$ & 0.0657 & \\
Total & & & & \\
\hline
\end{tabular}

ANOVA SUMMARY TABLE GRADUATE

EDUCATION STUDENTS, FALL 1972

\begin{tabular}{|c|c|c|c|c|c|}
\hline Source & & d.f. & ss & MS & $\mathbf{F}$ \\
\hline Treatment & & 39 & 1.8793 & 0.0481 & 1.34 \\
\hline Error & .. ' & 39 & 1.3958 & 0.0357 & 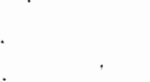 \\
\hline Total. & . & 78 & 3.2751 & & \\
\hline
\end{tabular}

*Significant $p<.01$ 
ANOVA SUMMARY TABLE OTHER MAJOR

GROUPS ON EDUCATION, FALL 1972

\begin{tabular}{|c|c|c|c|c|c|}
\hline Source & $\because$ & $d: f$ & SS & MS & $F$ \\
\hline Treatment & $\therefore$ & 44 & 9.2308 & $\quad 0.2097$ & 1.40 \\
\hline Error & & 88 & 13.1397 & 0.1493 & \\
\hline Total & $\therefore$ & 132 & 22.3705 & & \\
\hline
\end{tabular}

ANOVA SUMMARY TABLE ELEMENTARY

EDUCATION MAJORS, FALL 1973

\begin{tabular}{llcll}
\hline Source & d.f. & SS & MS & F \\
\hline Treatment & 39 & 22.9872 & 0.5894 & $9.16 *$ \\
Error & $\frac{117}{156}$ & $\frac{7.5278}{30.5662}$ & 0.0643 & \\
Total & $:$ & 156 & & \\
\hline
\end{tabular}

*Significant $\mathrm{p}<.01$ 
ANOVA SUMMARY TABLE GRADUATE

EDUCATION STUDENTS, FALL 1973

\begin{tabular}{lcccc}
\hline Source & d.f. & SS & MS & F \\
\hline Treatment & 39 & 1.5567 & 0.0399 & $9.50 *$ \\
Error & $\frac{39}{78}$ & $\underline{0.1658}$ & 0.0042 & \\
Total & 1.7225 & & \\
\hline
\end{tabular}

ANOVA SUMMARY TABLE OTHER MAJOR

GROUPS ON EDUCATION, FALL 1973

\begin{tabular}{lcrlll}
\hline Source & d.f. & SS & MS & F \\
\hline Treatment & 44 & 5.5396 & 0.1259 & $1.62 *$ \\
Error & $\therefore \frac{132}{176}$ & $\frac{10.2922}{15.8318}$ & 0.0779 & \\
Total & 176 & \\
\hline
\end{tabular}

*Significant $p<.01$ 